\title{
Alzheimer's Disease: Another Target for Heparin Therapy
}

\author{
Luigi Bergamaschini ${ }^{1, *}$, Emanuela Rossi ${ }^{1}$, Carlo Vergani ${ }^{1}$, \\ and Maria Grazia De Simoni ${ }^{2}$ \\ ${ }^{1}$ Department of Internal Medicine, Geriatric Unit, Ospedale Maggiore Policlinico \\ IRCCS, University of Milan, Italy; ${ }^{2}$ Department of Neuroscience, Mario Negri Institute \\ for Pharmacological Research, Milan, Italy \\ E-mail: luigi.bergamaschini@unimi.it; ebrossi@infinito.it; carlo.vergani@unimi.it; desimoni@marionegri.it
}

Received May 24, 2009; Revised August 11, 2009; Accepted August 12, 2009; Published September 1, 2009

\begin{abstract}
Alzheimer's disease (AD) is the leading cause of dementia and cognitive decline in the elderly. Brain tissue changes indicate that the two main proteins involved in $A D$ are amyloid-beta $(A \beta)$, which is associated with the formation of senile amyloid plaques, and tau, which is associated with the formation of neurofibrillary tangles. Although a central role for $A \beta$ in the pathogenesis of $A D$ is indisputable, considerable evidence indicates that $A \beta$ production is not the sole culprit in $A D$ pathology. $A D$ is also accompanied by an inflammatory response that contributes to irreversible changes in neuronal viability and brain function, and accumulating evidence supports the pivotal role of complement and contact systems in its pathogenesis and progression. The complexity of AD pathology provides numerous potential targets for therapeutic interventions. Compounds that interact directly with $A \beta$ protein or interfere with its production and/or aggregation can reduce the inflammatory and neurotoxic effects of $A \beta$, and heparin, a glycosaminoglycan mixture currently used in the prophylaxis and treatment of thrombosis, might be a candidate, as recent research has been extended to consider its nonanticoagulant properties, including its modulation of various proteases and anti-inflammatory activity.
\end{abstract}

KEYWORDS: Alzheimer's disease, heparin, inflammation, amyloid-beta, complement system, contact/kinin system

\section{INTRODUCTION}

Alzheimer's disease (AD), the main cause of dementia in the elderly, is becoming an ever-increasing problem as the population ages[1,2,3]. Its basic pathological mechanism is represented by conformational changes in amyloid- $\beta$ peptides $(A \beta)$ and tau proteins, two normally expressed proteins that self-assemble into toxic $\beta$-pleated sheet aggregates, and its main histopathological features are neuritic plaques formed by the extracellular deposition of $A \beta$ and neurofibrillary tangles, which consist of intracellular aggregates of hyperphosphorylated tau proteins in the cytoplasm of neurons[4,5].

Normal tau promotes assembly and stabilized microtubules, but the nonfibrillized, abnormally hyperphosphorylated form sequesters normal tau and disrupts microtubules. The abnormal hyperphosphorylation also promotes misfolding, a decreased turnover, and self-assembly into tangles of 
paired helical or straight filaments[6]. Microtubule disruption and the aggregation of tau in neurofibrillary tangles probably impairs axoplasmic flow and leads to the slowly progressive retrograde degeneration and loss of connectivity of the affected neurons[7].

$\mathrm{A} \beta$ in neuritic plaques is a 39-43 residue peptide that is a cleavage product of the amyloid precursor protein (APP) [8,9]. Most physiological fluids, such as plasma and cerebral spinal fluid (CSF), contain derivatives of APP, including water-soluble A $\beta$ peptides. The aggregation of these monomeric A $\beta$ peptides into oligomeric forms is associated with conformational changes and neurotoxicity in $\mathrm{AD}[10,11,12]$, although it is still not known whether this aggregation and the deposition of the oligomers in plaques are steps in the same pathway[13].

It is thought that apolipoprotein $\mathrm{E}$ (ApoE, and especially its $\varepsilon 4$ isoform), $\alpha 1$-antichymotrypsin, and $\mathrm{C} 1 \mathrm{q}$ complement factor increase the formation of $\mathrm{A} \beta$ fibrils from water-soluble $\mathrm{A} \beta$, and promote and stabilize the transformation[14,15,16,17,18]. It is also thought that one critical event in the pathological mechanism of $\mathrm{AD}$ is the reaching of a crucial concentration of water-soluble $\mathrm{A} \beta$ or chaperone proteins in the brain, at which point the conformational changes lead to the formation of aggregates and thus initiate a neurodegenerative cascade. In the case of sporadic $\mathrm{AD}$, this crucial concentration might be reached because of any combination of the age-associated, over-production of $\mathrm{A} \beta$, impaired brain clearance, and the influx of circulatory $A \beta$ into the central nervous system[19].

Given the central role of $\mathrm{A} \beta$ in the pathogenesis of $\mathrm{AD}$, research in the last decade was aimed at developing therapies that target amyloid production, aggregation, clearance, or toxicity[20,21,22, $23,24,25]$. In this area, $\beta$-secretase inhibitors[26,27,28,29,30], statins[31,32,33,34,35], and $A \beta$ vaccination procedures $[36,37,38,39,40]$ that aimed to inhibit $A \beta$ production or accumulation appear to be some of the more promising approaches.

However, although the $\mathrm{A} \beta$ cascade hypothesis is one of the prevalent theories[41], some researchers suggest that this accumulation may not be sufficient to cause cognitive impairment[42], but it is necessary to trigger a series of other events (including the up-regulation of inflammatory responses, tau processing, and changes in free radicals) that cause self-perpetuating brain injury[43,44]. There is strong evidence that inflammation is characteristic of $\mathrm{AD}[45]$ in human beings and animal models: the senile plaques are decorated by a number of inflammatory proteins, complement and kinin system factors, and $\mathrm{A} \beta$ deposition is accompanied by the attraction and activation of microglia and astrocytes, which leads to increased secretions of proinflammatory cytokines as part of a neuroinflammatory response[20].

Although the mechanism by which $A \beta$ induces toxicity is still poorly understood, it is possible that therapies that target $A \beta$ toxicity, such as modulation of the $A \beta$-mediated inflammatory reaction, will be developed. Given their many effects, heparins and heparin-related compounds could be valuable therapeutic candidates[46,47,48,49,50,51,52,53,54,55,56].

\section{MULTIPLE FUNCTIONS OF HEPARIN}

Heparin, a linear sulfated polysaccharide chain, belongs to the family of glycosaminoglycans (GAGs) that play important roles in blood clotting, neuronal communication, brain development, and cancer by binding to different proteins[57,58]. GAG families have different molecular weights, charge densities, degrees of sulfation, and types of disaccharide units, which create an enormous number of protein-binding motifs and are responsible for their biological activities[59].

GAGs have been considered of interest in AD ever since they were first demonstrated in amyloid plaques and neurofibrillary tangles. In vitro, heparan sulfate proteoglycans (HSPGs) may regulate APP processing by Alzheimer's $\beta$-secretase and may enhance $A \beta$ fibrillogenesis, but they may also prevent the persistence of the toxic forms of $\mathrm{A} \beta$ oligomers or protofibrils by transforming them into more harmless aggregates[21], and proteoglycan analogue dextran sulfate and chondroitin sulfate may modulate the activation of the classical and alternative complement pathways[60,61,62,63]. The precise role of GAGs in $\mathrm{AD}$ is, therefore, still controversial. 
Heparin is a highly sulfated GAG consisting of hexuronic acid and D-glucosamine residues joined by glycoside linkages[64]. Its most widely accepted function is as an anticoagulant and antithrombotic agent, mainly due to its ability to potentiate antithrombin III activity[65,66]. The early studies of heparin structure and function concentrated on the interactions responsible for its inhibition of blood coagulation, but the observation that heparin-containing tissues are in direct contact with the external environment suggests it may also play a role in host defense. Heparin binds a number of growth factors[67], as well as extracellular matrix proteins[68,69,70,71], proteins involved in lipid metabolism (such as apolipoprotein) $[72,73,74]$, and acute phase[75,76,77,78,79,80,81] and complement factors $[82,83,84,85$, 86,87]. There is also accumulating evidence that it interferes with the adhesion of leukocytes to the endothelium, a mechanism that plays a central role in the inflammatory response.

Furthermore, heparin may also be involved in regulating apoptosis[64,88]. There is evidence that it can modulate the activity of tumor necrosis factor (TNF) and nuclear factor kappa B (NF-kB), two key members of the apoptotic cascade; it can inhibit the enzymes responsible for DNA fragmentation in apoptotic cells[89]; and it can bind with high affinity to leukocyte receptors during apoptosis[90].

\section{POSSIBLE BENEFICIAL ACTIONS OF GAGS AND HEPARIN IN AD}

Proteins undergo various types of post-translational modifications in cells under normal and stressed conditions. In some cases, the modified protein has reduced conformational stability and, therefore, an increased propensity to misfold and aggregate. One of the post-translational modifications that promote the aggregation of some proteins is proteolysis, and the most intensively studied example of a fibrillogenic polypeptide generated by proteolysis is the amyloid peptide.

Evidence that $A \beta$ accumulation probably contributes to AD provides the rationale for a therapy based on altering brain $A \beta$ accumulation and reducing its cytotoxic and proinflammatory action. The $A \beta$ peptide is generated from APP: APP is initially cleaved by $\beta$-secretase, which is pivotal for the subsequent cleavage of APP fragments by $\gamma$-secretase that leads to the long fibrillar A $\beta 1-40$ and A $\beta 1-42$ peptides (Fig. 1). In $\mathrm{AD}$, these peptides aggregate to form plaques within the brain. The protease responsible for $\beta$ secretase activity in neurons has been identified as $\beta$-site APP-cleaving enzyme 1 (BACE-1)[91], whose activity is crucial to the amyloidogenic processing of APP. An interesting recent study showed increased BACE-1 protein and enzymatic activity within AD brain homogenates, thus further supporting the hypothesis that abnormal BACE-1 activity is associated with the disease. When assessing the in vivo CSF concentration of BACE-1 and its activity, the authors found increased levels of both in subjects with MCI (mild cognitive impairment) in comparison with healthy controls and AD patients, thus demonstrating the early presence of abnormal BACE-1 concentrations in a group at risk for $\mathrm{AD}$ [92].

It is known that heparin and heparan sulfate regulate the activity of a number of proteases, and it has been reported that heparin inhibits BACE-1 activity in vitro[93]. It has been found that a low concentration of heparin can stimulate recombinant human BACE-1 activity in vitro, and stimulation by heparin leads to increased autocatalysis cleavage of the protease domain and a subsequent loss of enzyme activity[46]. Patey et al. evaluated engineered heparin analogues (including modifications designed to increase bioavailability) as novel BACE-1 inhibitors in vitro and found that a number of the tested compounds were effective; they also provided insights into the structural interaction between BACE-1 and heparin, indicating that the structure of the polysaccharide is much more important than its charge[56].

In vitro, charged residues within the 1-11 region are critical for $\mathrm{A} \beta$ proinflammatory activity[94,95,96]; thus, inhibiting this activity by pharmacologically targeting this region may also be useful in slowing the progression of neurodegeneration in the AD brain. One candidate for such a therapy is heparin $\square[50,52,53,54]$. 


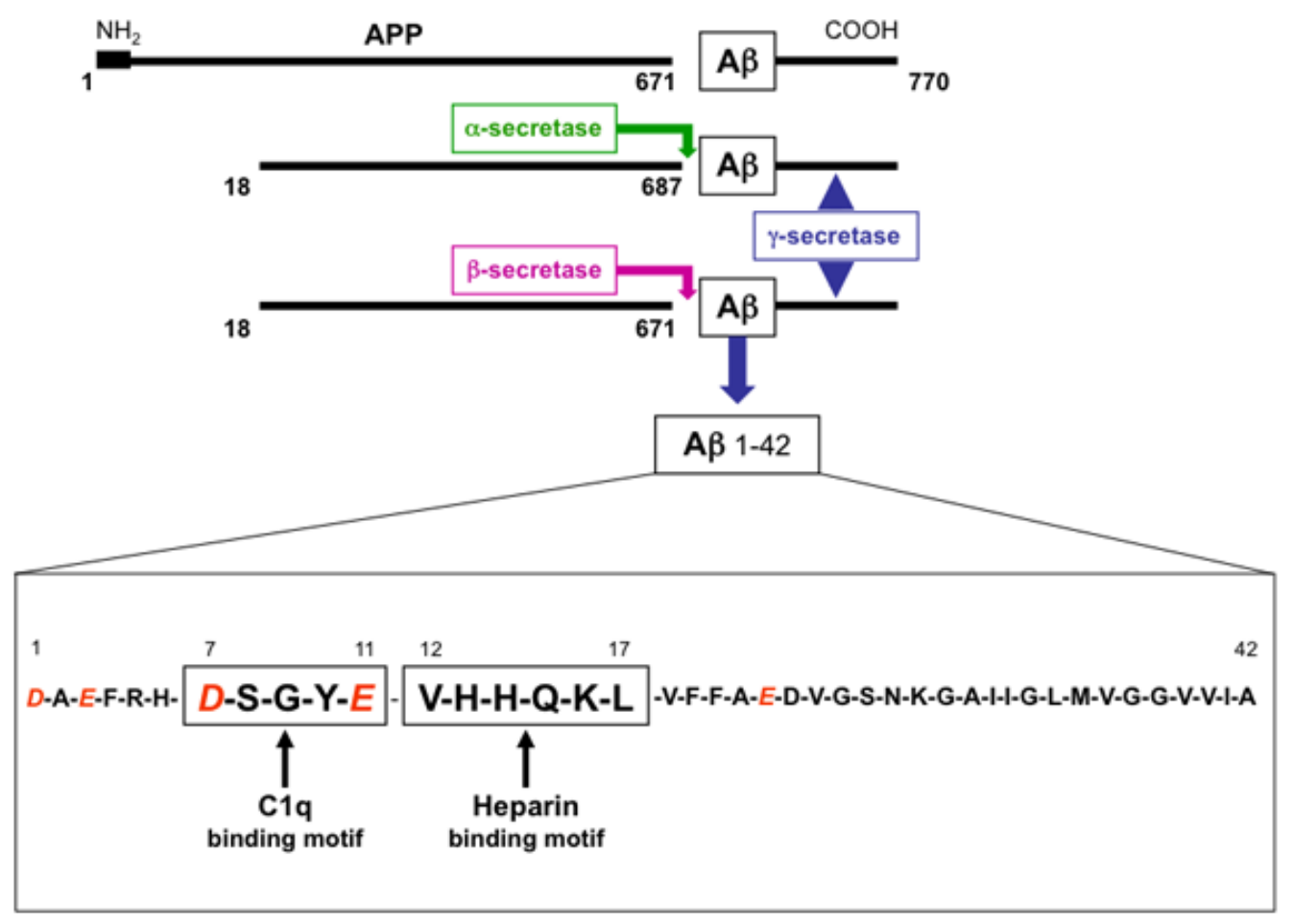

FIGURE 1. Amino acid sequence of Alzheimer's A $\beta$, the 39-43 residue peptide derived from proteolytic cleavage of the APP. Negatively charged residues are in red. The binding site of heparin (residues 12-17) could give place to a steric hindrance to the negatively charged residues within the region (residues 1-11) that is critical for the activation of complement and contact/kinin systems.

The heparin binding site on $A \beta$ is the 13-16 region (HHQK) of the $A \beta$ peptide, and represents the only target for the prevention of $A \beta$ fibril formation. Heparin can prevent more than $70 \%$ of its binding to HSPGs and may block the cell surface adherence of A $\beta$. Either effect could protect neurons and vascular endothelial cells against the toxic effects of $A \beta$. It has been demonstrated that GAGs and other sulfatecontaining compounds significantly attenuate the toxic effect of $\mathrm{A} \beta$ on neuronal differentiated PC12 cells[48,97,98,99], and their association with $\mathrm{A} \beta$ may prevent aggregation from occurring or induce aggregation of a different kind from that producing the intermolecularly stacked $\beta$-pleated sheet aggregates characteristic of the toxic form of $A \beta$. Alternatively, they might coat the aggregated $A \beta$ in such a way that it cannot interact efficiently with cells to produce its toxic response or displace its interactions with cell-surface HSPGs.

\section{HEPARIN AND METAL CATIONS}

$\mathrm{A} \beta$ is a metalloprotein that possesses a selective high- and low-affinity metal binding site[100,101]. Both ionic zinc and copper accelerate the aggregation of $A \beta$ and promote release of reactive oxygen species from cells[102,103,104,105,106,107,108]. The AD brain seems to be characterized by elevated iron levels and an accumulation of copper $\left(\mathrm{Cu}^{2+}\right)$ and zinc $\left(\mathrm{Zn}^{2+}\right)$ in the hippocampus, the region of the AD brain more severely affected, in the CSF, and senile plaques[109,110]. In 1994, Bush and Tanzi discovered for the first time that $\mathrm{A} \beta$ becomes amyloidogenic in reaction to stoichiometric amounts of $\mathrm{Zn}^{2+}$ and $\mathrm{Cu}^{2+}[111,112]$, and recently they coined "The Metal Hypothesis of AD", which proposed that the interaction of $\mathrm{A} \beta$ with these two metals drives $\mathrm{A} \beta$ pathogenicity and downstream $\mathrm{AD}$ pathology[113]. 
Classically, $\mathrm{Zn}^{2+}$ and $\mathrm{Cu}^{2+}$ ions bind heparin, modulating its anticoagulant activity[114,115,116]. Nevertheless, heparin might act positively in $\mathrm{AD}$ by binding these cations and thus reducing their unwanted activities, namely on APP physiology and A $\beta$ aggregation[102,111,112,117]. It has been shown recently that heparin could also have an important role in the modulation of the activity of the extracellular superoxide dismutase (SOD)[118]. SOD3, a homotetrameric $\mathrm{Cu}^{2+}$ - and $\mathrm{Zn}^{2+}$-containing glycoprotein, plays multiple roles[119,120,121,122], including retention of memory[123]. The importance of heparin in SOD3 activity is suggested by the increased risk of myocardial infarctions and stroke in individuals that carry a common polymorphism, R213G, which reduces the heparin affinity of SOD3[124].

\section{HEPARIN AND ITS ANTI-INFLAMMATORY ACTION}

One of the downstream events involved in AD is a chronic inflammatory response. Over the last 20 years, a wide range of inflammatory markers that are not usually found in normal elderly subjects have been reported in AD patients[125] and increasing evidence suggests that sustained brain inflammation may be an essential cofactor in the pathogenesis of $\mathrm{AD}[126,127]$. In addition to its direct cytotoxic effect, $\mathrm{A} \beta$ triggers a local inflammatory reaction that stimulates astrocytes, microglia, and cerebral vascular endothelial cells to produce a variety of inflammatory mediators, including cytokines and superoxide radicals that may be responsible for the chronic neurodegeneration. There is growing evidence to support the pivotal role of two inflammatory cascades in the pathogenesis or progression of AD: the complement and contact/kinin systems[94,127,128,129](Fig. 2).

\section{The Complement System}

The complement system forms part of the innate immune system and has three major physiological activities: to defend against bacterial infection, to bring together innate and adaptive immunity, and to clear immune complexes and the products of inflammatory injury. As a key mediator of inflammation, complement contributes to tissue damage in various clinical disorders. It is activated by means of three pathways: the classical antibody-dependent pathway, the alternative pathway, and the lectin pathway leading to the formation of the cytolytic membrane attack complex C5b-9 (MAC)[130,131]. After complement activation, the biologically active peptides $\mathrm{C} 5 \mathrm{a}$ and $\mathrm{C} 3 \mathrm{a}$ elicit a number of proinflammatory effects, such as chemotaxis; the degranulation of phagocytic cells, mast cells, and basophils; smooth muscle contraction; and increased vascular permeability. Upon cell activation by these complement products, the inflammatory response is further amplified by the subsequent generation of toxic oxygen radicals, and the induction of the synthesis and release of arachidonic acid metabolites and cytokines[132,133].

Under physiological conditions, complement activation is effectively controlled by the action of a number of soluble inhibitors (C1-inhibitor [C1-INH], C4 binding protein, factors $\mathrm{H}$ and I, S-protein [vitronectin and clusterin]) and surface proteins (complement receptor 1, the membrane cofactor protein [MCP, CD46], decay-accelerating factor, the C8-binding protein, and CD59)[134].

Clinical and experimental evidence underlines the major role of complement in the pathogenesis of numerous inflammatory diseases, including neurodegenerative disorders such as $\mathrm{AD}$, multiple sclerosis, and Guillain-Barré syndrome[45,135,136,137,138,139,140,141,142,143,144,145,146,147,148].

In the brain of $\mathrm{AD}$ patients, complement factors such as C1q, C4, C3, factor B, and C5b-9 have been found to colocalize with amyloid plaques and vascular amyloid in the cerebral cortex and hippocampus[149,150,151], as well as with myelin and membranes[152,153,154]. In vitro, A $\beta$ fibrils activate the classical complement pathway by directly binding to C1q[95,96,152,153,155, $156,157,158,159,160]$ and the alternative pathway via interactions with C3[54,161]. 


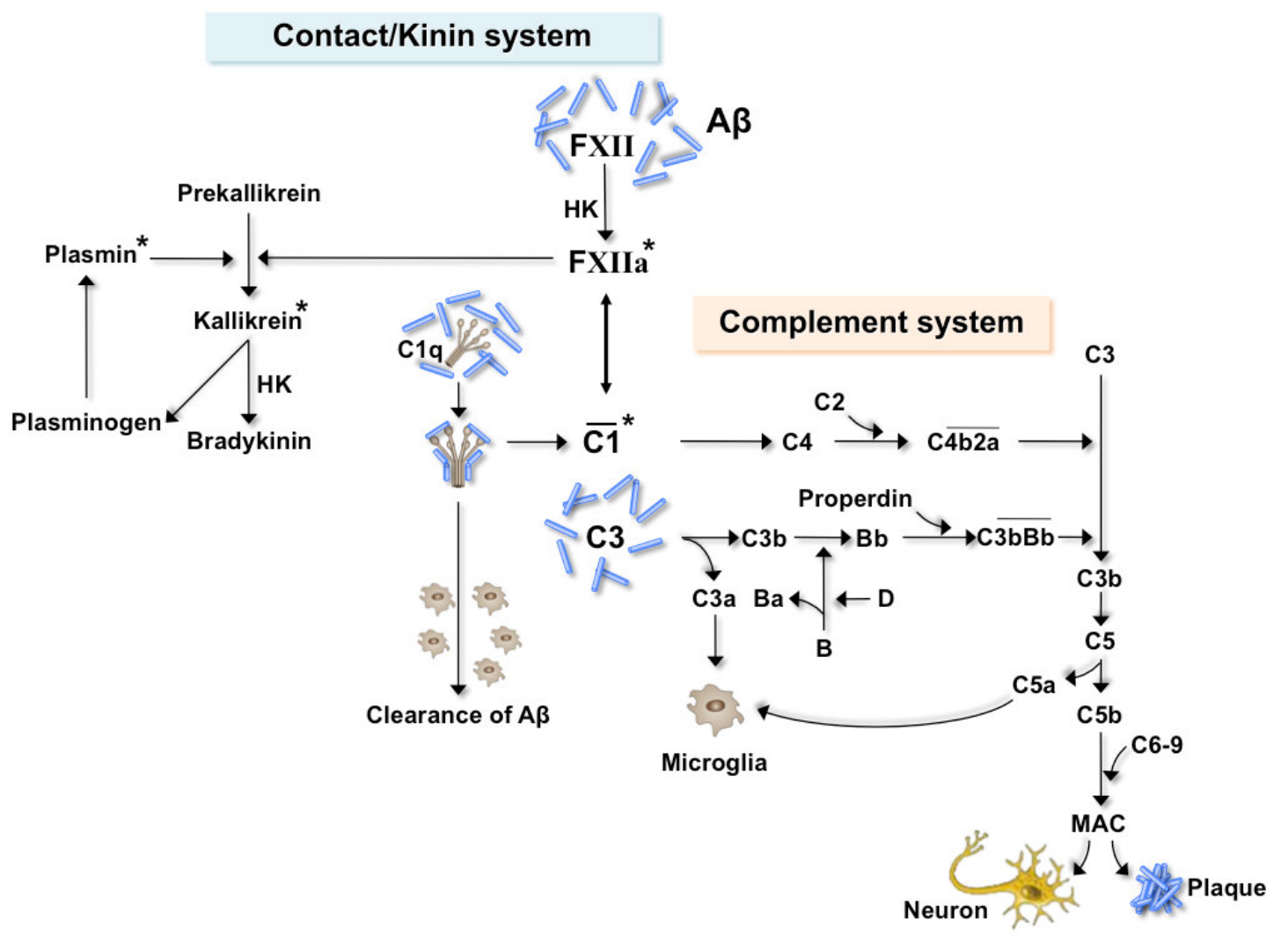

FIGURE 2. Schematic representation of the A $\beta$-dependent activation of complement and contact/kinin systems. Activation of contact system can lead to a C1q-independent activation of the complement classical pathway. Complement and contact/kinin systems share C1-INH as a major inhibitor (* = sites of action). In the AD brain, complement (both classical and alternative pathways) could induce both a detrimental effect (C3, MAC deposition on plaques, recruitment and activation of microglia, neurodegeneration) and neuroprotection (clearance of $\mathrm{A} \beta$ fibrils, promotion of neurogenesis), according to the degree of its activation.

Complement activation is common in $\mathrm{AD}$, but its contribution to the pathogenesis of the disease is controversial[134]. It has been suggested that it may protect against $A \beta$-induced neurotoxicity and even contribute to reducing the accumulation of $\mathrm{A} \beta$ in senile plaques. By increasing the efficiency of glial phagocytosis, $\mathrm{C} 1 \mathrm{q}$ binding to fibrillar $\mathrm{A} \beta$ and the subsequent formation of the $\mathrm{C} 4$ and $\mathrm{C} 3$ opsonins, and $\mathrm{C} 3 \mathrm{a}$ and $\mathrm{C} 5 \mathrm{a}$ chemoattractant anaphylatoxins, may accelerate $\mathrm{A} \beta$ clearance and thus reduce its deposition. In transgenic animals, complement inhibition leads to increased $\mathrm{AD}$, whereas increased $\mathrm{C} 3$ production reduces $A \beta$ deposition[162]. However, complement activation may also lead to neurodegeneration. A $\beta$ dependent complement activation induces microglial activation, thus leading to the secretion of proinflammatory cytokines and further $\mathrm{A} \beta$ generation, both of which accelerate neurodegeneration[21].

Various research groups have demonstrated that heparin can regulate complement activation at different sites of the cascade by means of a mechanism that is independent of antithrombin III affinity[163,164,165,166,167,168,169,170]. It increases the activity of C1-INH[87,171,172], interferes with the interactions of $\mathrm{C} 4$ with $\mathrm{C} 1$ and $\mathrm{C} 2$, prevents the formation of the $\mathrm{C} 3$ amplification loop of the alternative pathway, and attenuates the proinflammatory activities of anaphylatoxin C5a and MACdependent hemolysis[53,173]. We have also found that heparin abolishes the ability of $\mathrm{A} \beta$ to activate $\mathrm{C} 4$ in a dose-dependent manner[48]. The binding sites of heparin and C1q are, respectively, located between residues 12 and 17 (-H-H-Q-K-)[54] and residues 7 and 11 within the N-terminal region of $A \beta[160]$, and so the heparin-induced prevention of $\mathrm{C} 4$ activation is also in line with the hypothesis that this drug may sterically interfere with the binding of $\mathrm{C} 1 \mathrm{q}$ to $\mathrm{A} \beta$. 


\section{The Contact/Kinin System}

A further mechanism of activating the complement cascade is the activation of the contact/kinin system, which occurs in a C1q-independent manner and leads to the generation of kinins[174,175,176,177].

The contact system consists of zymogens factor XII (fXII), factor XI (fXI), and prekallikrein (PK), and the nonenzymatic high-molecular-weight kininogen cofactor (HK) $[178,179,180,181,182,183]$. fXII self-activates (fXIIa) as a result of contact with a variety of artificial or biologically negative surfaces (contact activation), which leads to blood coagulation and the activation of the inflammatory kallikrein/kinin and complement systems. The fXIIa activation of fXI initiates a series of proteolytic reactions that lead to the thrombin generation preceding clot formation, whereas the fXIIa-dependent activation of PK forms kallikrein, which reciprocally activates more fXII and releases bradykinin from HK. fXIIa then activates the macromolecule complex of the first component of complement, thus leading to the activation of the classical complement system; kallikrein also directly activates complement components C3 and C5[178,184]. Alternatively, increased fibrinolytic activity may activate early complement factors as plasmin can activate C1s in vitro and in vivo[185,186,187].

Most of the biological surfaces that activate fXII are expressed in disease states, and investigators have long searched for the physiological activators of fXII and its role in vivo. Maas et al. recently showed that the misfolded protein aggregates produced during systemic amyloidosis allow plasma fXIIa and PK activation, and the increased formation of kallikrein-C1-INH complexes, without fXI activation and coagulation. This study described a novel biological surface for fXII activation and activity, which initiates inflammatory events independently of hemostasis[188]. We previously demonstrated that HK, a marker of contact system activation, is massively cleaved in the CSF, but not in the plasma of AD patients, which suggests that system activation is a characteristic of the AD brain[94]. Region 1-11 of $A \beta$ is critical for contact system activation and heparin can prevent the $A \beta$-dependent cleavage of $\mathrm{HK}$ in a dose-dependent manner[47]. The unique heparin binding site on $A \beta$ is located between residues 12 and 17 (-H-H-Q-K-) and this could have sterically hindered the negatively charged residues within region 1$11[95]$.

There is also evidence that inhibiting thrombin activity may be a useful effect of heparin in AD. Thrombin activates platelets, a major source of APP and A $\beta$ release into the bloodstream[189,190], and thrombin receptors on activated platelets can trigger complement activation in the fluid phase. Furthermore, the accumulation of thrombin in neurofibrillary tangles supports the hypothesis that it may also be involved in tau proteolysis[191].

An experimental model of $\mathrm{AD}$ recently revealed a significant increase in the density of both kinin receptors (B1 and B2) in the brains of rats after the intracerebroventricular infusion of $A \beta[192]$. Tissue plasminogen factor (tPA), the primary activator of plasminogen to plasmin in the brain, colocalized with the $\mathrm{A} \beta$ plaques, but tPA protein levels were the same as in age-matched control brain tissue. However, as shown for the first time by Fabbro et al., tPA activity in the AD brain is greatly reduced in comparison with age-matched control brain tissue and this may be responsible for the diminished levels of plasmin in $\mathrm{AD}[193]$. Plasmin readily cleaves both fibrillar and monomeric $\mathrm{A} \beta$, thus making it an attractive candidate for $A \beta$ clearance.

Despite these several lines of evidence supporting the hypothesis that the contact system may be involved in $\mathrm{AD}$, it remains to be ascertained whether the functional disturbance of neurons or glial cells is at least partially attributable to the generation of bradykinin induced by contact/kinin system activation. In any case, the activation of fXII and PK leads to the generation of enzymes that react with C1-INH to form fXIIa-C1-INH and kallikrein-C1-INH complexes. In situ hybridization has revealed that only neurons express C1-INH mRNA in brain areas with neuritic plaques and activated glial cells, and not the cells (such as astrocytes) that usually produce the complex. Defective synthesis combined with an increased rate of consumption and up-regulated production of complement factor may therefore lead to a functional deficiency in $\mathrm{C} 1-\mathrm{INH}$, and this local deficiency may facilitate the activation of complement in the affected areas of the AD brain[194]. 
In clinical terms, heparin-induced potentiation of C1-INH activity may be interesting in AD[195,196]. The presence of a single, major, positively charged region on the contact surface of C1-INH has led to consideration of the simplest sufficient mechanism of GAGs potentiation of C1-INH: charge neutralization. Heparin-like GAGs regulate the catalytic activity of fXIa during interactions with the macromolecular substrate and inhibitors such as the serpins antithrombin (AT) and C1-INH. The results obtained by Yang et al. suggest that basic residues of fXIa form a heparin-binding site, and that the accelerating effect of heparin on the inhibition of fXIa by AT or C1-INH may be mediated by charge neutralization and/or allosteric mechanisms that overcome the repulsive inhibitory interactions of serpins with these basic residues[87].

\section{HEPARIN AND APOLIPOPROTEIN E}

ApoE is a constituent of many lipoproteins that transport lipids between cells throughout the circulatory system[197]. Three common isoforms are expressed in humans: $A p o E \varepsilon_{2}, A p o E \varepsilon_{3}$, and $A p o E \varepsilon_{4}$, all of which are products of alleles at a single gene locus. In the brain, ApoE is primarily produced by glial cells and its receptors are abundantly expressed by neurons. By accelerating $\mathrm{A} \beta$ aggregation towards mature fibril formation, (human) ApoE prevents the formation of toxic $A \beta$ intermediates such as oligomers and protofibrils, and may protect against the development of $\mathrm{AD}$ by suppressing the inflammatory reactions associated with $\mathrm{AD}$ lesions[14]. In addition to inducing conformational changes in $\mathrm{A} \beta$, ApoE facilitates $\mathrm{A} \beta$ clearance from the brain by acting as an $\mathrm{A} \beta$ transporter across the blood-brain barrier (BBB): both the ApoE isoform and the ApoE lipidation state affect $A \beta$ clearance. ApoE $\varepsilon_{4}$ forms a less stable complex with $\mathrm{A} \beta$ than $\mathrm{ApoE} \varepsilon_{3}$ or $\mathrm{ApoE} \varepsilon_{2}$, thus reducing $\mathrm{A} \beta$ transport efficiency across the $\mathrm{BBB}$ and more efficiently enhancing $A \beta$ aggregation than $A p o E \varepsilon_{3}$, which also inhibits clearance[21]. In a recent study, Deane et al. showed that $A \beta$ binding to $A p o E \varepsilon_{4}$ redirected the rapid clearance of unbound $A \beta 40$ and $A \beta 42$ from LDL receptor-related protein-1 (LRP1) to the VLDL receptor (VLDLR), which has a substantially slower endocytotic rate than LRP1 and slowly clears $A p o E \varepsilon_{4}$ and $A \beta-A p o E \varepsilon_{4}$ complexes[198]. In addition to colocalizing with $\mathrm{A} \beta$ in $\mathrm{AD}$ brains, ApoE is also found in neurons containing neurofibrillary tangles, where it interacts directly with tau protein. Furthermore, ApoE has an isoform-dependent effect on tau phosphorylation: $\mathrm{ApoE} \varepsilon_{3}$ binds to tau in vitro, but $\mathrm{ApoE} \varepsilon_{4}$ does not. An $\mathrm{ApoE} \varepsilon_{4}$-dependent increase in phosphorylated tau has also been observed.

The ApoE genotype is the only established genetic risk factor for late-onset sporadic AD[199]. The ApoE $\varepsilon_{4}$ genotype is more frequent in sporadic and familial late-onset $\mathrm{AD}$, occurring in about $52 \%$ of all cases of familial AD as against $16 \%$ of healthy controls[200]. In elderly people without dementia, the $\mathrm{ApoE} \varepsilon_{4}$ allele is associated with a more than twofold greater risk for developing $\mathrm{AD}$ [201]. In subjects with $\mathrm{MCI}$, the presence of the $\mathrm{ApoE} \varepsilon_{4}$ genotype is a strong predictor of progression to $\mathrm{AD}[202,203]$. Various lines of research suggest that the $A p o E \varepsilon_{4}$ allele may be associated with $\mathrm{AD}$ by means of its role in the development of amyloid disease. ApoE $\varepsilon_{4}$ has been related to increased $\mathrm{A} \beta$ production and deposition and, as discussed above, BACE- 1 is pivotal for $\mathrm{A} \beta$ generation, and a new study has shown an association between the ApoE $\varepsilon_{4}$ genotype and BACE-1 activity measured in the CSF of AD and MCI subjects[92].

There is evidence that the highly positively charged $\mathrm{APOE} \varepsilon_{4}$ lysine (Lys) and arginine (Arg) residues (Arg-Lys-Leu[leucine]-Lys-Arg) can bind A $\beta$ monomers, which are unable to polymerize and assemble into large aggregates, thus accelerating fibril formation and maintaining fibril stability. An early study[204] found that heparin inhibits the effects of Lys and Arg by binding to positively charged ApoE $\varepsilon_{4}$ residues, thus minimizing the effects of $\mathrm{ApoE}_{4}$ and having a beneficial effect on the pathogenesis of $\mathrm{AD}[205,206,207,208,209,210]$. 


\section{CONCLUSION}

$\mathrm{AD}$ is characterized by a decline in intellectual function that is severe enough to interfere with normal daily activities and social relationships. Its neuropathological hallmarks are amyloid deposition in senile plaques, neurofibrillary tangles, and neuronal cell loss in a number of cortical and subcortical regions. Although the exact pathogenesis of AD has not yet been fully defined, various pharmacological strategies for preventing and treating it are being actively investigated, some of which involve the interactions of some compounds with the production and aggregation of $A \beta$. Moreover, a new drug has targeted the molecular events involved in $\mathrm{AD}$, such as the cytotoxicity of $\mathrm{A} \beta$ and its ability to trigger a robust local inflammatory reaction.

Heparin has been proposed as a promising agent because of its multiple effects on the pathogenesis of $\mathrm{AD}$, including its potential competitive interactions with proteoglycans, vascular effects, interactions with serpins, and anti-inflammatory activity. Given the relationships between these different mechanisms, the pleiotropic effects of heparin and heparin-related compounds may have greater therapeutic potential than compounds directed against a single target. As heparin remains one of the most important anticoagulant drugs in clinical practice, a greater understanding of the structure-activity relationships between its anticoagulant effects and anti-inflammatory mechanisms has aroused increased interest in heparin and its derivatives as a new treatment of inflammatory disease. The therapeutic use of GAGs in the brain is limited by the extent to which the different compounds penetrate the BBB and, therefore, their molecular weight. Low-molecular-weight GAGs, including low-molecular-weight heparin (LMWH), may have more therapeutic value than molecularly heavier substances. Two important findings have provided a basis for the development of heparin oligosaccharides in this area: heparin's inhibition of inflammatory responses is independent of its anticoagulant activity, and heparin oligosaccharides have similar or even better anti-inflammatory effects than heparin itself[55,64]. Dudas et al.[211,212] recently demonstrated that some similar low-molecular-weight GAGs (certoparin, C3, C6) are capable of crossing the BBB and preventing $A \beta$-induced conformational changes in tau and reactive astrocytosis. Our previous in vitro studies demonstrated that enoxaparin, a LMWH, is as capable as heparin of attenuating the neurotoxicity and proinflammatory activity of $A \beta$. We also found that prophylactic treatment with a clinically relevant dose of enoxaparin reduces reactive astrocytosis, and the deposition and total brain concentration of $A \beta$ in a mouse model of $\mathrm{AD}$ (APP23 mice), and the absence of an inflammatory reaction and brain hemorrhaging suggests that the long-term treatment was well tolerated[49]. We are currently conducting a preclinical study of a prophylactic dose of enoxaparin and the preliminary 3-month results indicate that it is well tolerated by AD patients.

This paper summarizes the possible beneficial effects of heparins that are distinct from their wellknown anticoagulant activity, but more experimental data are needed in order to define the relationship between their structure and antiamyloid effects (Fig. 3). 


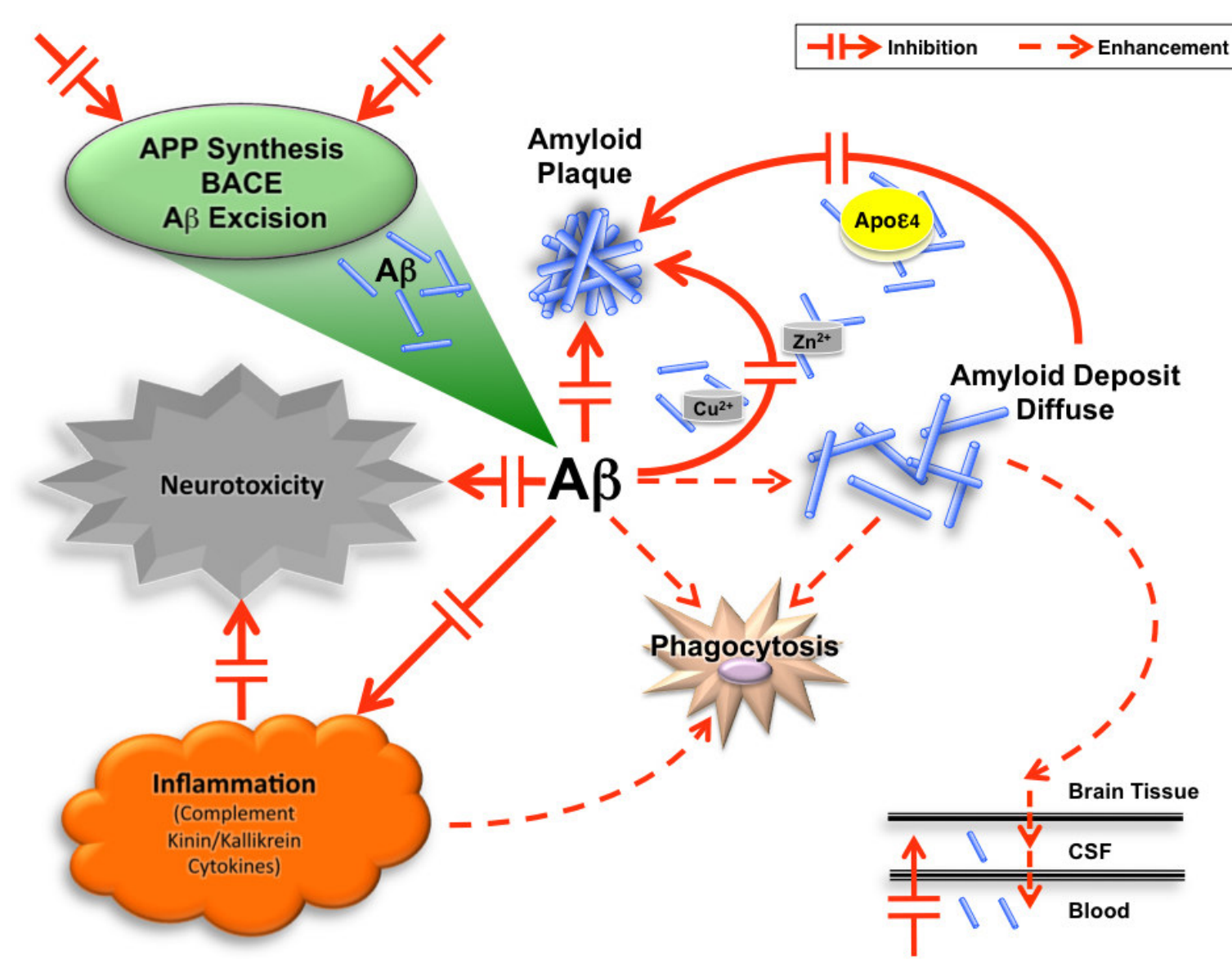

FIGURE 3. Possible protective mechanisms of heparins in $\mathrm{AD}$ pathology: reduction of $\mathrm{A} \beta$ generation by an action on APP processing or metabolism, prevention of $A \beta$ aggregation/deposition in senile plaques, inhibition of $A \beta$-driven toxic effects (inflammation, neurotoxicity), reduction of the inflammatory response (complement, kinin system), facilitation of $\mathrm{A} \beta$ removal from the brain compartment.

\section{REFERENCES}

1. Selkoe, D.J. (1991) The molecular pathology of Alzheimer's disease. Neuron 6, 487-498.

2. Selkoe, D.J. (1997) Alzheimer's disease: genotypes, phenotypes, and treatments. Science 275, 630-631.

3. Jonsson, L. and Wimo, A. (2009) The cost of dementia in Europe: a review of the evidence, and methodological considerations. Pharmacoeconomics 27, 391-403.

4. Regland, B. and Gottfries, C.G. (1992) The role of amyloid beta-protein in Alzheimer's disease. Lancet 340, 467-469.

5. Jellinger, K.A. and Bancher, C. (1996) AD neuropathology. Neurology 46, 1186-1187.

6. Huang, H.C. and Jiang, Z.F. (2009) Accumulated amyloid-beta peptide and hyperphosphorylated tau protein: relationship and links in Alzheimer's disease. J. Alzheimers Dis. 16, 15-27.

7. Iqbal, K., Liu, F., Gong, C.X., Alonso, A.D., and Grundke-Iqbal, I. (2009) Mechanisms of tau-induced neurodegeneration. Acta Neuropathol. 118(1), 53-69.

8. $\quad$ Selkoe, D.J. (2001) Alzheimer's disease: genes, proteins, and therapy. Physiol. Rev. 81, 741-766.

9. Nathalie, P. and Jean-Noel, O. (2008) Processing of amyloid precursor protein and amyloid peptide neurotoxicity. Curr. Alzheimer Res. 5, 92-99.

10. Giulian, D., Haverkamp, L.J., Yu, J.H., Karshin, W., Tom, D., Li, J., Kirkpatrick, J., Kuo, L.M., and Roher, A.E. (1996) Specific domains of beta-amyloid from Alzheimer plaque elicit neuron killing in human microglia. $J$. Neurosci. 16, 6021-6037.

11. Kuo, Y.M., Emmerling, M.R., Vigo-Pelfrey, C., Kasunic, T.C., Kirkpatrick, J.B., Murdoch, G.H., Ball, M.J., and Roher, A.E. (1996) Water-soluble Abeta (N-40, N-42) oligomers in normal and Alzheimer disease brains. J. Biol. Chem. 271, 4077-4081. 
12. Roher, A.E., Chaney, M.O., Kuo, Y.M., Webster, S.D., Stine, W.B., Haverkamp, L.J., Woods, A.S., Cotter, R.J., Tuohy, J.M., Krafft, G.A., Bonnell, B.S., and Emmerling, M.R. (1996) Morphology and toxicity of Abeta-(1-42) dimer derived from neuritic and vascular amyloid deposits of Alzheimer's disease. J. Biol. Chem. 271, 20631-20635.

13. Di Carlo, M. (2009) Beta amyloid peptide: from different aggregation forms to the activation of different biochemical pathways. Eur. Biophys. J. [Epub ahead of print]

14. Bu, G. (2009) Apolipoprotein E and its receptors in Alzheimer's disease: pathways, pathogenesis and therapy. Nat. Rev. 10, 333-344.

15. Kok, E., Haikonen, S., Luoto, T., Huhtala, H., Goebeler, S., Haapasalo, H., and Karhunen, P.J. (2009) Apolipoprotein E-dependent accumulation of Alzheimer disease-related lesions begins in middle age. Ann. Neurol. 65, 650-657.

16. Schipper, H.M. (2009) Apolipoprotein E: Implications for AD neurobiology, epidemiology and risk assessment. Neurobiol. Aging [Epub ahead of print]

17. Zhao, L., Lin, S., Bales, K.R., Gelfanova, V., Koger, D., Delong, C., Hale, J., Liu, F., Hunter, J.M., and Paul, S.M. (2009) Macrophage-mediated degradation of beta-amyloid via an apolipoprotein $\mathrm{E}$ isoform-dependent mechanism. $J$. Neurosci. 29, 3603-3612.

18. Zhong, N. and Weisgraber, K.H. (2009) Understanding the association of apolipoprotein E4 with Alzheimer disease: clues from its structure. J. Biol. Chem. 284, 6027-6031.

19. Finder, V.H. and Glockshuber, R. (2007) Amyloid-beta aggregation. Neurodegener. Dis. 4, 13-27.

20. Weiner, H.L. and Frenkel, D. (2006) Immunology and immunotherapy of Alzheimer's disease. Nat. Rev. Immunol. 6, 404-416.

21. Wilhelmus, M.M., de Waal, R.M., and Verbeek, M.M. (2007) Heat shock proteins and amateur chaperones in amyloid-Beta accumulation and clearance in Alzheimer's disease. Mol. Neurobiol. 35, 203-216.

22. Bates, K.A., Verdile, G., Li, Q.X., Ames, D., Hudson, P., Masters, C.L., and Martins, R.N. (2009) Clearance mechanisms of Alzheimer's amyloid-beta peptide: implications for therapeutic design and diagnostic tests. Mol. Psychiatry 14, 469-486.

23. Rochet, J.C. (2007) Novel therapeutic strategies for the treatment of protein-misfolding diseases. Expert Rev. Mol. Med. 9, 1-34.

24. Golde, T.E. (2006) Disease modifying therapy for AD? J. Neurochem. 99, 689-707.

25. Schmidt, R., Neff, F., Lampl, C., Benke, T., Anditsch, M., Bancher, C., Dal-Bianco, P., Reisecker, F., Marksteiner, J., Rainer, M., Kapeller, P., and Dodel, R. (2008) [Therapy of Alzheimer's disease: current status and future development]. Neuropsychiatrie 22, 153-171.

26. Ghosh, A.K., Gemma, S., and Tang, J. (2008) beta-Secretase as a therapeutic target for Alzheimer's disease. Neurotherapeutics 5, 399-408.

27. Ghosh, A.K., Kumaragurubaran, N., Hong, L., Koelsh, G., and Tang, J. (2008) Memapsin 2 (beta-secretase) inhibitors: drug development. Curr. Alzheimer Res. 5, 121-131.

28. Guo, T. and Hobbs, D.W. (2006) Development of BACE1 inhibitors for Alzheimer's disease. Curr. Med. Chem. 13, 1811-1829.

29. Serneels, L., Van Biervliet, J., Craessaerts, K., Dejaegere, T., Horre, K., Van Houtvin, T., Esselmann, H., Paul, S., Schafer, M.K., Berezovska, O., Hyman, B.T., Sprangers, B., Sciot, R., Moons, L., Jucker, M., Yang, Z., May, P.C., Karran, E., Wiltfang, J., D'Hooge, R., and De Strooper, B. (2009) gamma-Secretase heterogeneity in the Aph1 subunit: relevance for Alzheimer's disease. Science 324, 639-642.

30. Tomita, T. (2009) Secretase inhibitors and modulators for Alzheimer's disease treatment. Expert Rev. Neurother. 9, 661-679.

31. Boimel, M., Grigoriadis, N., Lourbopoulos, A., Touloumi, O., Rosenmann, D., Abramsky, O., and Rosenmann, H. (2009) Statins reduce the neurofibrillary tangle burden in a mouse model of tauopathy. J. Neuropathol. Exp. Neurol. 68, 314-325.

32. Haag, M.D., Hofman, A., Koudstaal, P.J., Stricker, B.H., and Breteler, M.M. (2009) Statins are associated with a reduced risk of Alzheimer disease regardless of lipophilicity. The Rotterdam Study. J. Neurol. Neurosurg. Psychiatry 80, 13-17.

33. Parsons, R.B., Farrant, J.K., Price, G.C., Subramaniam, D., and Austen, B.M. (2007) Regulation of the lipidation of beta-secretase by statins. Biochem. Soc. Trans. 35, 577-582.

34. Siegel, G.J., Chauhan, N.B., Feinstein, D.L., Li, G., Larson, E.B., Breitner, J.C., and Montine, T.J. (2008) Statin therapy is associated with reduced neuropathologic changes of Alzheimer disease. Neurology 71, 383; author reply 383.

35. Arvanitakis, Z., Schneider, J.A., Wilson, R.S., Bienias, J.L., Kelly, J.F., Evans, D.A., and Bennett, D.A. (2008) Statins, incident Alzheimer disease, change in cognitive function, and neuropathology. Neurology 70, 1795-1802.

36. Wisniewski, T. and Konietzko, U. (2008) Amyloid-beta immunisation for Alzheimer's disease. Lancet Neurol. 7, 805-811.

37. Schenk, D. (2002) Amyloid-beta immunotherapy for Alzheimer's disease: the end of the beginning. Nat. Rev. 3, 824828.

38. Morgan, D. (2006) Immunotherapy for Alzheimer's disease. J. Alzheimers Dis. 9, 425-432.

39. Haass, C. (2002) New hope for Alzheimer disease vaccine. Nat. Med. 8, 1195-1196. 
40. Levites, Y., Das, P., Price, R.W., Rochette, M.J., Kostura, L.A., McGowan, E.M., Murphy, M.P., and Golde, T.E. (2006) Anti-Abeta42- and anti-Abeta40-specific mAbs attenuate amyloid deposition in an Alzheimer disease mouse model. J. Clin. Invest. 116, 193-201.

41. Tanzi, R.E. and Bertram, L. (2005) Twenty years of the Alzheimer's disease amyloid hypothesis: a genetic perspective. Cell 120, 545-555.

42. Mormino, E.C., Kluth, J.T., Madison, C.M., Rabinovici, G.D., Baker, S.L., Miller, B.L., Koeppe, R.A., Mathis, C.A., Weiner, M.W., and Jagust, W.J. (2009) Episodic memory loss is related to hippocampal-mediated beta-amyloid deposition in elderly subjects. Brain 132, 1310-1323.

43. Castellani, R.J., Lee, H.G., Zhu, X., Perry, G., and Smith, M.A. (2008) Alzheimer disease pathology as a host response. J. Neuropathol. Exp. Neurol. 67, 523-531.

44. Hardy, J. (2009) The amyloid hypothesis for Alzheimer's disease: a critical reappraisal. J. Neurochem. 110(4), 11291134.

45. Salminen, A., Ojala, J., Kauppinen, A., Kaarniranta, K., and Suuronen, T. (2009) Inflammation in Alzheimer's disease: amyloid-beta oligomers trigger innate immunity defence via pattern recognition receptors. Prog. Neurobiol. 87, 181-194.

46. Beckman, M., Holsinger, R.M., and Small, D.H. (2006) Heparin activates beta-secretase (BACE1) of Alzheimer's disease and increases autocatalysis of the enzyme. Biochemistry 45, 6703-6714.

47. Bergamaschini, L., Donarini, C., Foddi, C., Gobbo, G., Parnetti, L., and Agostoni, A. (2001) The region 1-11 of Alzheimer amyloid-beta is critical for activation of contact-kinin system. Neurobiol. Aging 22, 63-69.

48. Bergamaschini, L., Donarini, C., Rossi, E., De Luigi, A., Vergani, C., and De Simoni, M.G. (2002) Heparin attenuates cytotoxic and inflammatory activity of Alzheimer amyloid-beta in vitro. Neurobiol. Aging 23, 531-536.

49. Bergamaschini, L., Rossi, E., Storini, C., Pizzimenti, S., Distaso, M., Perego, C., De Luigi, A., Vergani, C., and De Simoni, M.G. (2004) Peripheral treatment with enoxaparin, a low molecular weight heparin, reduces plaques and beta-amyloid accumulation in a mouse model of Alzheimer's disease. J. Neurosci. 24, 4181-4186.

50. Leveugle, B., Ding, W., Laurence, F., Dehouck, M.P., Scanameo, A., Cecchelli, R., and Fillit, H. (1998) Heparin oligosaccharides that pass the blood-brain barrier inhibit beta-amyloid precursor protein secretion and heparin binding to beta-amyloid peptide. J. Neurochem. 70, 736-744.

51. Leveugle, B. and Fillit, H. (1994) Proteoglycans and the acute-phase response in Alzheimer's disease brain. Mol. Neurobiol. 9, 25-32.

52. Leveugle, B., Scanameo, A., Ding, W., and Fillit, H. (1994) Binding of heparan sulfate glycosaminoglycan to betaamyloid peptide: inhibition by potentially therapeutic polysulfated compounds. Neuroreport 5, 1389-1392.

53. Tyrrell, D.J., Horne, A.P., Holme, K.R., Preuss, J.M., and Page, C.P. (1999) Heparin in inflammation: potential therapeutic applications beyond anticoagulation. Adv. Pharmacol. 46, 151-208.

54. Watson, D.J., Lander, A.D., and Selkoe, D.J. (1997) Heparin-binding properties of the amyloidogenic peptides Abeta and amylin. Dependence on aggregation state and inhibition by Congo red. J. Biol. Chem. 272, 31617-31624.

55. Ma, Q., Cornelli, U., Hanin, I., Jeske, W.P., Linhardt, R.J., Walenga, J.M., Fareed, J., and Lee, J.M. (2007) Heparin oligosaccharides as potential therapeutic agents in senile dementia. Curr. Pharm. Des. 13, 1607-1616.

56. Patey, S.J., Edwards, E.A., Yates, E.A., and Turnbull, J.E. (2008) Engineered heparins: novel beta-secretase inhibitors as potential Alzheimer's disease therapeutics. Neurodegener. Dis. 5, 197-199.

57. Gandhi, N.S. and Mancera, R.L. (2008) The structure of glycosaminoglycans and their interactions with proteins. Chem. Biol. Drug Des. 72, 455-482.

58. Shirai, K. and Chaudhary, U.B. (2007) Use of low molecular weight heparin and aminocaproic acid in chronic DIC associated with prostate cancer--a case report. TheScientificWorldJOURNAL 7, 753-755.

59. Casu, B. (1989) Structure and biological activity of mammalian glycosaminoglycans. Mod. Probl. Pharmacopsychiatry 23, 56-67.

60. Bos, I.G., van Mierlo, G.J., Bleeker, W.K., Rigter, G.M., te Velthuis, H., Dickneite, G., and Hack, C.E. (2001) The potentiation of human C1-inhibitor by dextran sulphate is transient in vivo: studies in a rat model. Int. Immunopharmacol. 1, 1583-1595.

61. Burger, R., Hadding, U., Schorlemmer, H.U., Brade, V., and Bitter-Suermann, D. (1975) Dextran sulphate: a synthetic activator of C3 via the alternative pathway. I. Influence of molecular size and degree of sulphation on the activation potency. Immunology 29, 549-554.

62.

Meri, S. and Pangburn, M.K. (1994) Regulation of alternative pathway complement activation by glycosaminoglycans: specificity of the polyanion binding site on factor H. Biochem. Biophys. Res. Commun. 198, 5259.

63. Quigg, R.J. (1992) Inhibition of the alternative pathway of complement by glomerular chondroitin sulphate proteoglycan. Immunology 76, 373-377.

64. Young, E. (2008) The anti-inflammatory effects of heparin and related compounds. Thromb. Res. 122, $743-752$.

65. Hirsh, J. (1991) Heparin. N. Engl. J. Med. 324, 1565-1574.

66. Weitz, J.I. (1997) Low-molecular-weight heparins. N. Engl. J. Med. 337, 688-698.

67. Lobb, R.R. (1988) Clinical applications of heparin-binding growth factors. Eur. J. Clin. Invest. 18, 321-336.

68. Casu, B., Vlodavsky, I., and Sanderson, R.D. (2008) Non-anticoagulant heparins and inhibition of cancer. Pathophysiol. Haemost. Thromb. 36, 195-203. 
69. Mitsi, M., Forsten-Williams, K., Gopalakrishnan, M., and Nugent, M.A. (2008) A catalytic role of heparin within the extracellular matrix. J. Biol. Chem. 283, 34796-34807.

70. Sugaya, N., Habuchi, H., Nagai, N., Ashikari-Hada, S., and Kimata, K. (2008) 6-O-sulfation of heparan sulfate differentially regulates various fibroblast growth factor-dependent signalings in culture. J. Biol. Chem. 283, 1036610376.

71. Trindade, E.S., Oliver, C., Jamur, M.C., Rocha, H.A., Franco, C.R., Boucas, R.I., Jarrouge, T.R., Pinhal, M.A., Tersariol, I.L., Gouvea, T.C., Dietrich, C.P., and Nader, H.B. (2008) The binding of heparin to the extracellular matrix of endothelial cells up-regulates the synthesis of an antithrombotic heparan sulfate proteoglycan. J. Cell. Physiol. 217, 328-337.

72. Beisiegel, U., Weber, W., and Bengtsson-Olivecrona, G. (1991) Lipoprotein lipase enhances the binding of chylomicrons to low density lipoprotein receptor-related protein. Proc. Natl. Acad. Sci. U. S. A. 88, 8342-8346.

73. Chevreuil, O., Hultin, M., Ostergaard, P., and Olivecrona, T. (1993) Biphasic effects of low-molecular-weight and conventional heparins on chylomicron clearance in rats. Arterioscler. Thromb. 13, 1397-1403.

74. Chevreuil, O., Hultin, M., Ostergaard, P., and Olivecrona, T. (1993) Depletion of lipoprotein lipase after heparin administration. Arterioscler. Thromb. 13, 1391-1396.

75. Fan, T.C., Fang, S.L., Hwang, C.S., Hsu, C.Y., Lu, X.A., Hung, S.C., Lin, S.C., and Chang, M.D. (2008) Characterization of molecular interactions between eosinophil cationic protein and heparin. J. Biol. Chem. 283, 25468-25474.

76. Hochart, H., Jenkins, P.V., Smith, O.P., and White, B. (2006) Low-molecular weight and unfractionated heparins induce a downregulation of inflammation: decreased levels of proinflammatory cytokines and nuclear factor-kappaB in LPS-stimulated human monocytes. Br. J. Haematol. 133, 62-67.

77. Gao, Y., Li, N., Fei, R., Chen, Z., Zheng, S., and Zeng, X. (2005) P-Selectin-mediated acute inflammation can be blocked by chemically modified heparin, RO-heparin. Mol. Cells 19, 350-355.

78. Mahoney, D.J., Mulloy, B., Forster, M.J., Blundell, C.D., Fries, E., Milner, C.M., and Day, A.J. (2005) Characterization of the interaction between tumor necrosis factor-stimulated gene- 6 and heparin: implications for the inhibition of plasmin in extracellular matrix microenvironments. J. Biol. Chem. 280, 27044-27055.

79. Johnson, Z., Kosco-Vilbois, M.H., Herren, S., Cirillo, R., Muzio, V., Zaratin, P., Carbonatto, M., Mack, M., Smailbegovic, A., Rose, M., Lever, R., Page, C., Wells, T.N., and Proudfoot, A.E. (2004) Interference with heparin binding and oligomerization creates a novel anti-inflammatory strategy targeting the chemokine system. J. Immunol. 173, 5776-5785.

80. Elsayed, E. and Becker, R.C. (2003) The impact of heparin compounds on cellular inflammatory responses: a construct for future investigation and pharmaceutical development. J. Thromb. Thrombolysis 15, 11-18.

81. Culley, F.J., Fadlon, E.J., Kirchem, A., Williams, T.J., Jose, P.J., and Pease, J.E. (2003) Proteoglycans are potent modulators of the biological responses of eosinophils to chemokines. Eur. J. Immunol. 33, 1302-1310.

82. Fabiana Alberto, M., Giaquinta Romero, D., Lazzari, M., and Calabrese, G.C. (2008) Antithrombotic and anticomplementary properties of a very low molecular mass dermatan sulfate. Thromb. Res. 122, 109-116.

83. Hellwage, J., Jokiranta, T.S., Koistinen, V., Vaarala, O., Meri, S., and Zipfel, P.F. (1999) Functional properties of complement factor H-related proteins FHR-3 and FHR-4: binding to the C3d region of C3b and differential regulation by heparin. FEBS Lett. 462, 345-352.

84. Murray-Rust, T.A., Kerr, F.K., Thomas, A.R., Wu, T., Tang, Y., Ong, P.C., Quinsey, N.S., Whisstock, J.C., Wagenaar-Bos, I.G., Freeman, C., and Pike, R.N. (2009) Modulation of the proteolytic activity of the complement protease $\mathrm{C} 1 \mathrm{~s}$ by polyanions: implications for polyanion-mediated acceleration of interaction between $\mathrm{C} 1 \mathrm{~s}$ and SERPING1. Biochem. J. 422(2), 295-303.

85. Perkins, S.J. and Goodship, T.H. (2002) Molecular modelling of the C-terminal domains of factor H of human complement: a correlation between haemolytic uraemic syndrome and a predicted heparin binding site. J. Mol. Biol. 316, 217-224.

86. Schmidt, C.Q., Herbert, A.P., Kavanagh, D., Gandy, C., Fenton, C.J., Blaum, B.S., Lyon, M., Uhrin, D., and Barlow, P.N. (2008) A new map of glycosaminoglycan and C3b binding sites on factor H. J. Immunol. 181, 2610-2619.

87. Yang, L., Sun, M.F., Gailani, D., and Rezaie, A.R. (2009) Characterization of a heparin-binding site on the catalytic domain of factor XIa: mechanism of heparin acceleration of factor XIa inhibition by the serpins antithrombin and C1inhibitor. Biochemistry 48, 1517-1524.

88. Krishnamoorthy, M., Heimburg-Molinaro, J., Bargo, A.M., Nash, R.J., and Nash, R.J. (2009) Heparin binding epidermal growth factor-like growth factor and PD169316 prevent apoptosis in mouse embryonic stem cells. $J$. Biochem. 145, 177-184.

89. Widlak, P. and Garrard, W.T. (2006) The apoptotic endonuclease DFF40/CAD is inhibited by RNA, heparin and other polyanions. Apoptosis 11, 1331-1337.

90. Gebska, M.A., Titley, I., Paterson, H.F., Morilla, R.M., Davies, D.C., Gruszka-Westwood, A.M., Kakkar, V.V., Eccles, S., and Scully, M.F. (2002) High-affinity binding sites for heparin generated on leukocytes during apoptosis arise from nuclear structures segregated during cell death. Blood 99, 2221-2227.

91. Vassar, R. (2005) beta-Secretase, APP and Abeta in Alzheimer's disease. Subcell. Biochem. 38, $79-103$. 
92. Ewers, M., Zhong, Z., Burger, K., Wallin, A., Blennow, K., Teipel, S.J., Shen, Y., and Hampel, H. (2008) Increased CSF-BACE 1 activity is associated with ApoE-epsilon 4 genotype in subjects with mild cognitive impairment and Alzheimer's disease. Brain 131, 1252-1258.

93. Scholefield, Z., Yates, E.A., Wayne, G., Amour, A., McDowell, W., and Turnbull, J.E. (2003) Heparan sulfate regulates amyloid precursor protein processing by BACE1, the Alzheimer's beta-secretase. J. Cell Biol. 163, 97-107.

94. Bergamaschini, L., Donarini, C., Gobbo, G., Parnetti, L., and Gallai, V. (2001) Activation of complement and contact system in Alzheimer's disease. Mech. Ageing Dev. 122, 1971-1983.

95. Velazquez, P., Cribbs, D.H., Poulos, T.L., and Tenner, A.J. (1997) Aspartate residue 7 in amyloid beta-protein is critical for classical complement pathway activation: implications for Alzheimer's disease pathogenesis. Nat. Med. 3, $77-79$.

96. Webster, S., Bonnell, B., and Rogers, J. (1997) Charge-based binding of complement component C1q to the Alzheimer amyloid beta-peptide. Am. J. Pathol. 150, 1531-1536.

97. Pollack, S.J., Sadler, I.I., Hawtin, S.R., Tailor, V.J., and Shearman, M.S. (1995) Sulfonated dyes attenuate the toxic effects of beta-amyloid in a structure-specific fashion. Neurosci. Lett. 197, 211-214.

98. Pollack, S.J., Sadler, I.I., Hawtin, S.R., Tailor, V.J., and Shearman, M.S. (1995) Sulfated glycosaminoglycans and dyes attenuate the neurotoxic effects of beta-amyloid in rat PC12 cells. Neurosci. Lett. 184, 113-116.

99. Woods, A.G., Cribbs, D.H., Whittemore, E.R., and Cotman, C.W. (1995) Heparan sulfate and chondroitin sulfate glycosaminoglycan attenuate beta-amyloid(25-35) induced neurodegeneration in cultured hippocampal neurons. Brain Res. 697, 53-62.

100. Atwood, C.S., Scarpa, R.C., Huang, X., Moir, R.D., Jones, W.D., Fairlie, D.P., Tanzi, R.E., and Bush, A.I. (2000) Characterization of copper interactions with Alzheimer amyloid beta peptides: identification of an attomolar-affinity copper binding site on amyloid beta1-42. J. Neurochem. 75, 1219-1233.

101. Danielsson, J., Pierattelli, R., Banci, L., and Graslund, A. (2007) High-resolution NMR studies of the zinc-binding site of the Alzheimer's amyloid beta-peptide. FEBS J. 274, 46-59.

102. House, E., Collingwood, J., Khan, A., Korchazkina, O., Berthon, G., and Exley, C. (2004) Aluminium, iron, zinc and copper influence the in vitro formation of amyloid fibrils of Abeta42 in a manner which may have consequences for metal chelation therapy in Alzheimer's disease. J. Alzheimers Dis. 6, 291-301.

103. Curtain, C.C., Ali, F.E., Smith, D.G., Bush, A.I., Masters, C.L., and Barnham, K.J. (2003) Metal ions, pH, and cholesterol regulate the interactions of Alzheimer's disease amyloid-beta peptide with membrane lipid. J. Biol. Chem. 278, 2977-2982.

104. Esler, W.P., Stimson, E.R., Jennings, J.M., Ghilardi, J.R., Mantyh, P.W., and Maggio, J.E. (1996) Zinc-induced aggregation of human and rat beta-amyloid peptides in vitro. J. Neurochem. 66, 723-732.

105. Karr, J.W., Kaupp, L.J., and Szalai, V.A. (2004) Amyloid-beta binds Cu2+ in a mononuclear metal ion binding site. $J$. Am. Chem. Soc. 126, 13534-13538.

106. Kowalik-Jankowska, T., Ruta-Dolejsz, M., Wisniewska, K., and Lankiewicz, L. (2001) Cu(II) interaction with Nterminal fragments of human and mouse beta-amyloid peptide. J. Inorg. Biochem. 86, 535-545.

107. Liu, S.T., Howlett, G., and Barrow, C.J. (1999) Histidine-13 is a crucial residue in the zinc ion-induced aggregation of the A beta peptide of Alzheimer's disease. Biochemistry 38, 9373-9378.

108. Van Nostrand, W.E. (1995) Zinc (II) selectively enhances the inhibition of coagulation factor XIa by protease nexin2/amyloid beta-protein precursor. Thromb. Res. 78, 43-53.

109. Lovell, M.A., Robertson, J.D., Teesdale, W.J., Campbell, J.L., and Markesbery, W.R. (1998) Copper, iron and zinc in Alzheimer's disease senile plaques. J. Neurol. Sci. 158, 47-52.

110. Basun, H., Forssell, L.G., Wetterberg, L., and Winblad, B. (1991) Metals and trace elements in plasma and cerebrospinal fluid in normal aging and Alzheimer's disease. J. Neural Transm. 3, 231-258.

111. Bush, A.I., Pettingell, W.H., Jr., de Paradis, M., Tanzi, R.E., and Wasco, W. (1994) The amyloid beta-protein precursor and its mammalian homologues. Evidence for a zinc-modulated heparin-binding superfamily. J. Biol. Chem. 269, 26618-26621.

112. Bush, A.I., Pettingell, W.H., Multhaup, G., d Paradis, M., Vonsattel, J.P., Gusella, J.F., Beyreuther, K., Masters, C.L., and Tanzi, R.E. (1994) Rapid induction of Alzheimer A beta amyloid formation by zinc. Science 265, 1464-1467.

113. Bush, A.I. and Tanzi, R.E. (2008) Therapeutics for Alzheimer's disease based on the metal hypothesis. Neurotherapeutics 5, 421-432.

114. Rudd, T.R., Skidmore, M.A., Guimond, S.E., Guerrini, M., Cosentino, C., Edge, R., Brown, A., Clarke, D.T., Torri, G., Turnbull, J.E., Nichols, R.J., Fernig, D.G., and Yates, E.A. (2008) Site-specific interactions of copper(II) ions with heparin revealed with complementary (SRCD, NMR, FTIR and EPR) spectroscopic techniques. Carbohydr. Res. 343, 2184-2193.

115. Grant, D., Long, W.F., and Williamson, F.B. (1992) A potentiometric titration study of the interaction of heparin with metal cations. Biochem. J. 285 (Pt 2), 477-480.

116. Fu, C.L. and Horn, M.K., 3rd (2002) Histidine-rich glycoprotein plus zinc to neutralize heparin. J. Lab. Clin. Med. 139, 211-217.

117. Bush, A.I., Multhaup, G., Moir, R.D., Williamson, T.G., Small, D.H., Rumble, B., Pollwein, P., Beyreuther, K., and Masters, C.L. (1993) A novel zinc(II) binding site modulates the function of the beta A4 amyloid protein precursor of Alzheimer's disease. J. Biol. Chem. 268, 16109-16112. 
118. Antonyuk, S.V., Strange, R.W., Marklund, S.L., and Hasnain, S.S. (2009) The structure of human extracellular copper-zinc superoxide dismutase at 1.7 A resolution: insights into heparin and collagen binding. J. Mol. Biol. 388, 310-326.

119. Beckman, J.S., Beckman, T.W., Chen, J., Marshall, P.A., and Freeman, B.A. (1990) Apparent hydroxyl radical production by peroxynitrite: implications for endothelial injury from nitric oxide and superoxide. Proc. Natl. Acad. Sci. U. S. A. 87, 1620-1624.

120. Carlsson, L.M., Jonsson, J., Edlund, T., and Marklund, S.L. (1995) Mice lacking extracellular superoxide dismutase are more sensitive to hyperoxia. Proc. Natl. Acad. Sci. U. S. A. 92, 6264-6268.

121. Jung, O., Marklund, S.L., Geiger, H., Pedrazzini, T., Busse, R., and Brandes, R.P. (2003) Extracellular superoxide dismutase is a major determinant of nitric oxide bioavailability: in vivo and ex vivo evidence from ecSOD-deficient mice. Circ. Res. 93, 622-629.

122. Kim, H.W., Lin, A., Guldberg, R.E., Ushio-Fukai, M., and Fukai, T. (2007) Essential role of extracellular SOD in reparative neovascularization induced by hindlimb ischemia. Circ. Res. 101, 409-419.

123. Levin, E.D., Brady, T.C., Hochrein, E.C., Oury, T.D., Jonsson, L.M., Marklund, S.L., and Crapo, J.D. (1998) Molecular manipulations of extracellular superoxide dismutase: functional importance for learning. Behav. Genet. 28, 381-390.

124. Juul, K., Tybjaerg-Hansen, A., Marklund, S., Heegaard, N.H., Steffensen, R., Sillesen, H., Jensen, G., and Nordestgaard, B.G. (2004) Genetically reduced antioxidative protection and increased ischemic heart disease risk: The Copenhagen City Heart Study. Circulation 109, 59-65.

125. Akiyama, H., Barger, S., Barnum, S., Bradt, B., Bauer, J., Cole, G.M., Cooper, N.R., Eikelenboom, P., Emmerling, M., Fiebich, B.L., Finch, C.E., Frautschy, S., Griffin, W.S., Hampel, H., Hull, M., Landreth, G., Lue, L., Mrak, R., Mackenzie, I.R., McGeer, P.L., O'Banion, M.K., Pachter, J., Pasinetti, G., Plata-Salaman, C., Rogers, J., Rydel, R., Shen, Y., Streit, W., Strohmeyer, R., Tooyoma, I., Van Muiswinkel, F.L., Veerhuis, R., Walker, D., Webster, S., Wegrzyniak, B., Wenk, G., and Wyss-Coray, T. (2000) Inflammation and Alzheimer's disease. Neurobiol. Aging 21, 383-421.

126. Eikelenboom, P., Rozemuller, J.M., Kraal, G., Stam, F.C., McBride, P.A., Bruce, M.E., and Fraser, H. (1991) Cerebral amyloid plaques in Alzheimer's disease but not in scrapie-affected mice are closely associated with a local inflammatory process. Virchows Arch. B Cell Pathol. Incl. Mol. Pathol. 60, 329-336.

127. Emmerling, M.R., Watson, M.D., Raby, C.A., and Spiegel, K. (2000) The role of complement in Alzheimer's disease pathology. Biochim. Biophys. Acta 1502, 158-171.

128. McGeer, E.G. and McGeer, P.L. (1999) Brain inflammation in Alzheimer disease and the therapeutic implications. Curr. Pharm. Des. 5, 821-836.

129. McGeer, P.L. and McGeer, E.G. (1999) Inflammation of the brain in Alzheimer's disease: implications for therapy. $J$. Leukoc. Biol. 65, 409-415.

130. Walport, M.J. (2001) Complement. Second of two parts. N. Engl. J. Med. 344, 1140-1144.

131. Walport, M.J. (2001) Complement. First of two parts. N. Engl. J. Med. 344, 1058-1066.

132. Head, E., Azizeh, B.Y., Lott, I.T., Tenner, A.J., Cotman, C.W., and Cribbs, D.H. (2001) Complement association with neurons and beta-amyloid deposition in the brains of aged individuals with Down Syndrome. Neurobiol. Dis. 8, 252265.

133. Veerhuis, R., van der Valk, P., Janssen, I., Zhan, S.S., Van Nostrand, W.E., and Eikelenboom, P. (1995) Complement activation in amyloid plaques in Alzheimer's disease brains does not proceed further than C3. Virchows Arch. 426, 603-610.

134. Sjoberg, A.P., Trouw, L.A., and Blom, A.M. (2009) Complement activation and inhibition: a delicate balance. Trends Immunol. 30, 83-90.

135. Ramaglia, V., King, R.H., Morgan, B.P., and Baas, F. (2009) Deficiency of the complement regulator CD59a exacerbates Wallerian degeneration. Mol. Immunol. 46, 1892-1896.

136. Beinrohr, L., Dobo, J., Zavodszky, P., and Gal, P. (2008) C1, MBL-MASPs and C1-inhibitor: novel approaches for targeting complement-mediated inflammation. Trends Mol. Med. 14, 511-521.

137. Tei, R., Kaido, T., Nakase, H., and Sakaki, T. (2008) Protective effect of C1 esterase inhibitor on acute traumatic spinal cord injury in the rat. Neurol. Res. 30, 761-767.

138. Maier, M., Peng, Y., Jiang, L., Seabrook, T.J., Carroll, M.C., and Lemere, C.A. (2008) Complement C3 deficiency leads to accelerated amyloid beta plaque deposition and neurodegeneration and modulation of the microglia/macrophage phenotype in amyloid precursor protein transgenic mice. J. Neurosci. 28, 6333-6341.

139. Griffiths, M., Neal, J.W., and Gasque, P. (2007) Innate immunity and protective neuroinflammation: new emphasis on the role of neuroimmune regulatory proteins. Int. Rev. Neurobiol. 82, 29-55.

140. Woodruff, T.M., Crane, J.W., Proctor, L.M., Buller, K.M., Shek, A.B., de Vos, K., Pollitt, S., Williams, H.M., Shiels, I.A., Monk, P.N., and Taylor, S.M. (2006) Therapeutic activity of C5a receptor antagonists in a rat model of neurodegeneration. FASEB J. 20, 1407-1417.

141. Bonifati, D.M. and Kishore, U. (2007) Role of complement in neurodegeneration and neuroinflammation. Mol. Immunol. 44, 999-1010. 
142. Leinhase, I., Schmidt, O.I., Thurman, J.M., Hossini, A.M., Rozanski, M., Taha, M.E., Scheffler, A., John, T., Smith, W.R., Holers, V.M., and Stahel, P.F. (2006) Pharmacological complement inhibition at the C3 convertase level promotes neuronal survival, neuroprotective intracerebral gene expression, and neurological outcome after traumatic brain injury. Exp. Neurol. 199, 454-464.

143. Storini, C., Rossi, E., Marrella, V., Distaso, M., Veerhuis, R., Vergani, C., Bergamaschini, L., and De Simoni, M.G. (2005) C1-inhibitor protects against brain ischemia-reperfusion injury via inhibition of cell recruitment and inflammation. Neurobiol. Dis. 19, 10-17.

144. de Jonge, R.R., van Schaik, I.N., Vreijling, J.P., Troost, D., and Baas, F. (2004) Expression of complement components in the peripheral nervous system. Hum. Mol. Genet. 13, 295-302.

145. van Beek, J., Elward, K., and Gasque, P. (2003) Activation of complement in the central nervous system: roles in neurodegeneration and neuroprotection. Ann. N. Y. Acad. Sci. 992, 56-71.

146. Yang, L.B., Li, R., Meri, S., Rogers, J., and Shen, Y. (2000) Deficiency of complement defense protein CD59 may contribute to neurodegeneration in Alzheimer's disease. J. Neurosci. 20, 7505-7509.

147. Gasque, P., Dean, Y.D., McGreal, E.P., VanBeek, J., and Morgan, B.P. (2000) Complement components of the innate immune system in health and disease in the CNS. Immunopharmacology 49, 171-186.

148. Barrington, R., Zhang, M., Fischer, M., and Carroll, M.C. (2001) The role of complement in inflammation and adaptive immunity. Immunol. Rev. 180, 5-15.

149. Eikelenboom, P. and Stam, F.C. (1984) An immunohistochemical study on cerebral vascular and senile plaque amyloid in Alzheimer's dementia. Virchows Arch. B Cell Pathol. Incl. Mol. Pathol. 47, 17-25.

150. Stoltzner, S.E., Grenfell, T.J., Mori, C., Wisniewski, K.E., Wisniewski, T.M., Selkoe, D.J., and Lemere, C.A. (2000) Temporal accrual of complement proteins in amyloid plaques in Down's syndrome with Alzheimer's disease. Am. J. Pathol. 156, 489-499.

151. Strohmeyer, R., Shen, Y., and Rogers, J. (2000) Detection of complement alternative pathway mRNA and proteins in the Alzheimer's disease brain. Brain Res. Mol. Brain Res. 81, 7-18.

152. Webster, S., Bradt, B., Rogers, J., and Cooper, N. (1997) Aggregation state-dependent activation of the classical complement pathway by the amyloid beta peptide. J. Neurochem. 69, 388-398.

153. Webster, S., Lue, L.F., Brachova, L., Tenner, A.J., McGeer, P.L., Terai, K., Walker, D.G., Bradt, B., Cooper, N.R., and Rogers, J. (1997) Molecular and cellular characterization of the membrane attack complex, C5b-9, in Alzheimer's disease. Neurobiol. Aging 18, 415-421.

154. Yasojima, K., Schwab, C., McGeer, E.G., and McGeer, P.L. (1999) Up-regulated production and activation of the complement system in Alzheimer's disease brain. Am. J. Pathol. 154, 927-936.

155. Zhou, J., Fonseca, M.I., Pisalyaput, K., and Tenner, A.J. (2008) Complement C3 and C4 expression in C1q sufficient and deficient mouse models of Alzheimer's disease. J. Neurochem. 106, 2080-2092.

156. Tenner, A.J. (2001) Complement in Alzheimer's disease: opportunities for modulating protective and pathogenic events. Neurobiol. Aging 22, 849-861.

157. Webster, S.D., Yang, A.J., Margol, L., Garzon-Rodriguez, W., Glabe, C.G., and Tenner, A.J. (2000) Complement component C1q modulates the phagocytosis of Abeta by microglia. Exp. Neurol. 161, 127-138.

158. Jiang, H., Burdick, D., Glabe, C.G., Cotman, C.W., and Tenner, A.J. (1994) beta-Amyloid activates complement by binding to a specific region of the collagen-like domain of the C1q A chain. J. Immunol. 152, 5050-5059.

159. Rogers, J., Cooper, N.R., Webster, S., Schultz, J., McGeer, P.L., Styren, S.D., Civin, W.H., Brachova, L., Bradt, B., Ward, P., et al. (1992) Complement activation by beta-amyloid in Alzheimer disease. Proc. Natl. Acad. Sci. U. S. A. 89, 10016-10020.

160. Tacnet-Delorme, P., Chevallier, S., and Arlaud, G.J. (2001) Beta-amyloid fibrils activate the C1 complex of complement under physiological conditions: evidence for a binding site for A beta on the C1q globular regions. $J$. Immunol. 167, 6374-6381.

161. Bradt, B.M., Kolb, W.P., and Cooper, N.R. (1998) Complement-dependent proinflammatory properties of the Alzheimer's disease beta-peptide. J. Exp. Med. 188, 431-438.

162. Wyss-Coray, T., Yan, F., Lin, A.H., Lambris, J.D., Alexander, J.J., Quigg, R.J., and Masliah, E. (2002) Prominent neurodegeneration and increased plaque formation in complement-inhibited Alzheimer's mice. Proc. Natl. Acad. Sci. U. S. A. 99, 10837-10842.

163. Calabrese, G.C., Alberto, M.F., Tubio, R., Marani, M.M., Fernandez De Recondo, M.E., Lazzari, M., and Recondo, E.F. (2004) A small fraction of dermatan sulfate with significantly increased anticoagulant activity was selected by interaction with the first complement protein. Thromb. Res. 113, 243-250.

164. Kozlov, L.V., Belkin, Z.P., Bichucher, A.M., Batalova, T.N., and Diakov, V.L. (2003) [Comparative effects of complement inhibitors in vitro and in vivo experiments: an immunoenzyme method in studying subcomponent $\mathrm{C} 1 \mathrm{q}$ inhibition and complement inhibition in model animals]. Biomed. Khim. 49, 284-290.

165. Lappegard, K.T., Fung, M., Bergseth, G., Riesenfeld, J., Lambris, J.D., Videm, V., and Mollnes, T.E. (2004) Effect of complement inhibition and heparin coating on artificial surface-induced leukocyte and platelet activation. Ann. Thorac. Surg. 77, 932-941.

166. Lappegard, K.T., Fung, M., Bergseth, G., Riesenfeld, J., and Mollnes, T.E. (2004) Artificial surface-induced cytokine synthesis: effect of heparin coating and complement inhibition. Ann. Thorac. Surg. 78, 38-44; discussion 44-35.

167. Tanzi, M.C. (2005) Bioactive technologies for hemocompatibility. Expert Rev. Med. Devices 2, 473-492. 
168. Vaziri-Sani, F., Hellwage, J., Zipfel, P.F., Sjoholm, A.G., Iancu, R., and Karpman, D. (2005) Factor H binds to washed human platelets. J. Thromb. Haemost. 3, 154-162.

169. Villoutreix, B.O., Hardig, Y., Wallqvist, A., Covell, D.G., Garcia de Frutos, P., and Dahlback, B. (1998) Structural investigation of C4b-binding protein by molecular modeling: localization of putative binding sites. Proteins 31, 391405.

170. Yu, H., Munoz, E.M., Edens, R.E., and Linhardt, R.J. (2005) Kinetic studies on the interactions of heparin and complement proteins using surface plasmon resonance. Biochim. Biophys. Acta 1726, 168-176.

171. Weiler, J.M., Edens, R.E., Linhardt, R.J., and Kapelanski, D.P. (1992) Heparin and modified heparin inhibit complement activation in vivo. J. Immunol. 148, 3210-3215.

172. Wuillemin, W.A., te Velthuis, H., Lubbers, Y.T., de Ruig, C.P., Eldering, E., and Hack, C.E. (1997) Potentiation of $\mathrm{C} 1$ inhibitor by glycosaminoglycans: dextran sulfate species are effective inhibitors of in vitro complement activation in plasma. J. Immunol. 159, 1953-1960.

173. Girardi, G., Redecha, P., and Salmon, J.E. (2004) Heparin prevents antiphospholipid antibody-induced fetal loss by inhibiting complement activation. Nat. Med. 10, 1222-1226.

174. Joseph, K., Shibayama, Y., Ghebrehiwet, B., and Kaplan, A.P. (2001) Factor XII-dependent contact activation on endothelial cells and binding proteins $\mathrm{gClqR}$ and cytokeratin 1. Thromb. Haemost. 85, 119-124.

175. Kaplan, A.P., Joseph, K., and Shibayama, Y. (1997) Binding of activation of kinin-forming proteins on vascular endothelial cells. Immunopharmacology 36, 201-207.

176. Kaplan, A.P., Joseph, K., Shibayama, Y., Reddigari, S., and Ghebrehiwet, B. (2001) Activation of the plasma kinin forming cascade along cell surfaces. Int. Arch. Allergy Immunol. 124, 339-342.

177. Kaplan, A.P., Joseph, K., Shibayama, Y., Reddigari, S., Ghebrehiwet, B., and Silverberg, M. (1997) The intrinsic coagulation/kinin-forming cascade: assembly in plasma and cell surfaces in inflammation. Adv. Immunol. 66, 225272.

178. Schmaier, A.H. (2008) The elusive physiologic role of Factor XII. J. Clin. Invest. 118, 3006-3009.

179. Schmaier, A.H. (2008) Assembly, activation, and physiologic influence of the plasma kallikrein/kinin system. Int. Immunopharmacol. 8, 161-165.

180. Schmaier, A.H. and McCrae, K.R. (2007) The plasma kallikrein-kinin system: its evolution from contact activation. $J$. Thromb. Haemost. 5, 2323-2329.

181. Schmaier, A.H. (1998) Plasma contact activation: a revised hypothesis. Biol. Res. 31, 251-262.

182. Colman, R.W. and Schmaier, A.H. (1997) Contact system: a vascular biology modulator with anticoagulant, profibrinolytic, antiadhesive, and proinflammatory attributes. Blood 90, 3819-3843.

183. DeLa Cadena, R.A., Majluf-Cruz, A., Stadnicki, A., Agosti, J.M., Colman, R.W., and Suffredini, A.F. (1996) Activation of the contact and fibrinolytic systems after intravenous administration of endotoxin to normal human volunteers: correlation with the cytokine profile. Immunopharmacology 33, 231-237.

184. Amara, U., Rittirsch, D., Flierl, M., Bruckner, U., Klos, A., Gebhard, F., Lambris, J.D., and Huber-Lang, M. (2008) Interaction between the coagulation and complement system. Adv. Exp. Med. Biol. 632, 71-79.

185. Naff, G.B. and Ratnoff, O.S. (1968) The enzymatic nature of C'1r. Conversion of C'1s to C'1 esterase and digestion of amino acid esters by C'1r. J. Exp. Med. 128, 571-593.

186. Ratnoff, O.D. and Naff, G.B. (1967) The conversion of C'IS to C'1 esterase by plasmin and trypsin. J. Exp. Med. 125, 337-358.

187. Ratnoff, O.D., Pensky, J., Ogston, D., and Naff, G.B. (1969) The inhibition of plasmin, plasma kallikrein, plasma permeability factor, and the $\mathrm{C}^{\prime} 1 \mathrm{r}$ subcomponent of the first component of complement by serum $\mathrm{C}^{\prime} 1$ esterase inhibitor. J. Exp. Med. 129, 315-331.

188. Maas, C., Govers-Riemslag, J.W., Bouma, B., Schiks, B., Hazenberg, B.P., Lokhorst, H.M., Hammarstrom, P., ten Cate, H., de Groot, P.G., Bouma, B.N., and Gebbink, M.F. (2008) Misfolded proteins activate factor XII in humans, leading to kallikrein formation without initiating coagulation. J. Clin. Invest. 118, 3208-3218.

189. Casoli, T., Di Stefano, G., Giorgetti, B., Grossi, Y., Balietti, M., Fattoretti, P., and Bertoni-Freddari, C. (2007) Release of beta-amyloid from high-density platelets: implications for Alzheimer's disease pathology. Ann. N. Y. Acad. Sci. 1096, 170-178.

190. Chen, M., Inestrosa, N.C., Ross, G.S., and Fernandez, H.L. (1995) Platelets are the primary source of amyloid betapeptide in human blood. Biochem. Biophys. Res. Commun. 213, 96-103.

191. Arai, T., Miklossy, J., Klegeris, A., Guo, J.P., and McGeer, P.L. (2006) Thrombin and prothrombin are expressed by neurons and glial cells and accumulate in neurofibrillary tangles in Alzheimer disease brain. J. Neuropathol. Exp. Neurol. 65, 19-25.

192. Viel, T.A., Lima Caetano, A., Nasello, A.G., Lancelotti, C.L., Nunes, V.A., Araujo, M.S., and Buck, H.S. (2008) Increases of kinin B1 and B2 receptors binding sites after brain infusion of amyloid-beta 1-40 peptide in rats. Neurobiol. Aging 29, 1805-1814.

193. Fabbro, S. and Seeds, N.W. (2009) Plasminogen activator activity is inhibited while neuroserpin is up-regulated in the Alzheimer disease brain. J. Neurochem. 109(2), 303-315.

194. Sarvari, M., Vago, I., Weber, C.S., Nagy, J., Gal, P., Mak, M., Kosa, J.P., Zavodszky, P., and Pazmany, T. (2003) Inhibition of C1q-beta-amyloid binding protects hippocampal cells against complement mediated toxicity. $J$. Neuroimmunol. 137, 12-18. 
195. Caldwell, E.E., Andreasen, A.M., Blietz, M.A., Serrahn, J.N., VanderNoot, V., Park, Y., Yu, G., Linhardt, R.J., and Weiler, J.M. (1999) Heparin binding and augmentation of C1 inhibitor activity. Arch. Biochem. Biophys. 361, 215222.

196. Caughman, G.B., Boackle, R.J., and Vesely, J. (1982) A postulated mechanism for heparin's potentiation of C1 inhibitor function. Mol. Immunol. 19, 287-295.

197. Mahley, R.W. (1988) Apolipoprotein E: cholesterol transport protein with expanding role in cell biology. Science 240, 622-630.

198. Deane, R., Sagare, A., Hamm, K., Parisi, M., Lane, S., Finn, M.B., Holtzman, D.M., and Zlokovic, B.V. (2008) apoE isoform-specific disruption of amyloid beta peptide clearance from mouse brain. J. Clin. Invest. 118, 4002-4013.

199. Rademakers, R., Cruts, M., and Van Broeckhoven, C. (2003) Genetics of early-onset Alzheimer dementia. TheScientificWorldJOURNAL 3, 497-519.

200. Strittmatter, W.J., Saunders, A.M., Schmechel, D., Pericak-Vance, M., Enghild, J., Salvesen, G.S., and Roses, A.D. (1993) Apolipoprotein E: high-avidity binding to beta-amyloid and increased frequency of type 4 allele in late-onset familial Alzheimer disease. Proc. Natl. Acad. Sci. U. S. A. 90, 1977-1981.

201. Slooter, A.J., Houwing-Duistermaat, J.J., van Harskamp, F., Cruts, M., Van Broeckhoven, C., Breteler, M.M., Hofman, A., Stijnen, T., and van Duijn, C.M. (1999) Apolipoprotein E genotype and progression of Alzheimer's disease: the Rotterdam Study. J. Neurol. 246, 304-308.

202. Petersen, R.C., Smith, G.E., Ivnik, R.J., Tangalos, E.G., Schaid, D.J., Thibodeau, S.N., Kokmen, E., Waring, S.C., and Kurland, L.T. (1995) Apolipoprotein E status as a predictor of the development of Alzheimer's disease in memory-impaired individuals. JAMA 273, 1274-1278.

203. Tierney, M.C., Szalai, J.P., Snow, W.G., Fisher, R.H., Nores, A., Nadon, G., Dunn, E., and St. George-Hyslop, P.H. (1996) Prediction of probable Alzheimer's disease in memory-impaired patients: a prospective longitudinal study. Neurology 46, 661-665.

204. Weisgraber, K.H. and Shinto, L.H. (1991) Identification of the disulfide-linked homodimer of apolipoprotein E3 in plasma. Impact on receptor binding activity. J. Biol. Chem. 266, 12029-12034.

205. Bazin, H.G., Marques, M.A., Owens, A.P., 3rd, Linhardt, R.J., and Crutcher, K.A. (2002) Inhibition of apolipoprotein E-related neurotoxicity by glycosaminoglycans and their oligosaccharides. Biochemistry 41, 8203-8211.

206. Dong, J., Peters-Libeu, C.A., Weisgraber, K.H., Segelke, B.W., Rupp, B., Capila, I., Hernaiz, M.J., LeBrun, L.A., and Linhardt, R.J. (2001) Interaction of the N-terminal domain of apolipoprotein E4 with heparin. Biochemistry 40, 28262834.

207. Libeu, C.P., Lund-Katz, S., Phillips, M.C., Wehrli, S., Hernaiz, M.J., Capila, I., Linhardt, R.J., Raffai, R.L., Newhouse, Y.M., Zhou, F., and Weisgraber, K.H. (2001) New insights into the heparan sulfate proteoglycan-binding activity of apolipoprotein E. J. Biol. Chem.276, 39138-39144.

208. Sadowski, M., Pankiewicz, J., Scholtzova, H., Ripellino, J.A., Li, Y., Schmidt, S.D., Mathews, P.M., Fryer, J.D., Holtzman, D.M., Sigurdsson, E.M., and Wisniewski, T. (2004) A synthetic peptide blocking the apolipoprotein E/beta-amyloid binding mitigates beta-amyloid toxicity and fibril formation in vitro and reduces beta-amyloid plaques in transgenic mice. Am. J. Pathol. 165, 937-948.

209. Saito, H., Dhanasekaran, P., Nguyen, D., Baldwin, F., Weisgraber, K.H., Wehrli, S., Phillips, M.C., and Lund-Katz, S. (2003) Characterization of the heparin binding sites in human apolipoprotein E. J. Biol. Chem. 278, 14782-14787.

210. Shuvaev, V.V. and Siest, G. (2000) Heparin specifically inhibits binding of apolipoprotein E to amyloid beta-peptide. Neurosci. Lett. 280, 131-134.

211. Dudas, B., Cornelli, U., Lee, J.M., Hejna, M.J., Walzer, M., Lorens, S.A., Mervis, R.F., Fareed, J., and Hanin, I. (2002) Oral and subcutaneous administration of the glycosaminoglycan C3 attenuates Abeta(25-35)-induced abnormal tau protein immunoreactivity in rat brain. Neurobiol. Aging 23, 97-104.

212. Dudas, B., Rose, M., Cornelli, U., Pavlovich, A., and Hanin, I. (2008) Neuroprotective properties of glycosaminoglycans: potential treatment for neurodegenerative disorders. Neurodegener. Dis. 5, 200-205.

\section{This article should be cited as follows:}

Bergamaschini, L., Rossi, E., Vergani, C., and De Simoni, M.G. (2009) Alzheimer's disease: another target for heparin therapy. TheScientificWorldJOURNAL 9, 891-908. DOI 10.1100/tsw.2009.100. 


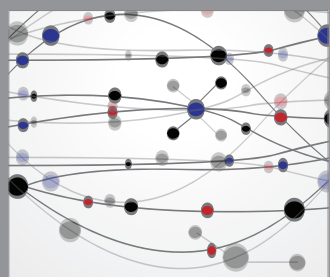

The Scientific World Journal
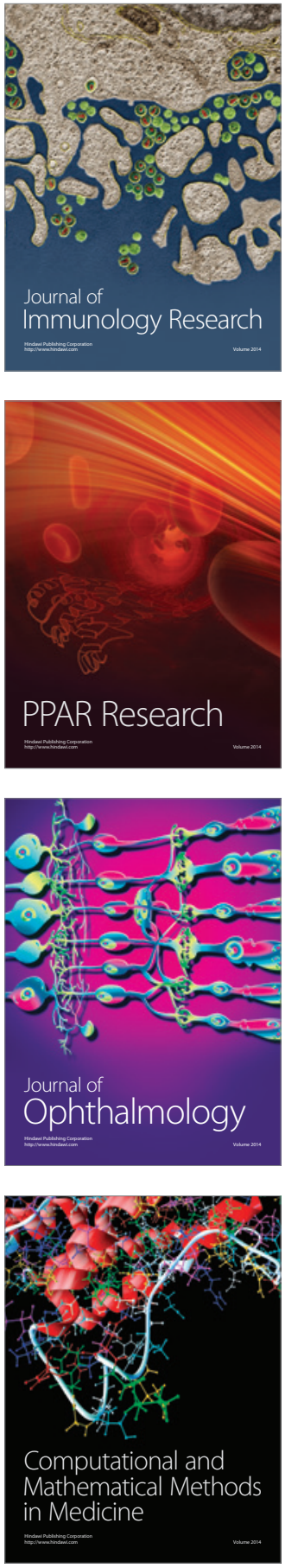

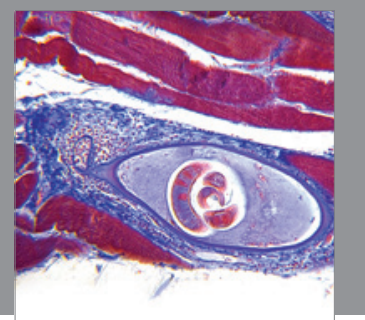

Gastroenterology

Research and Practice
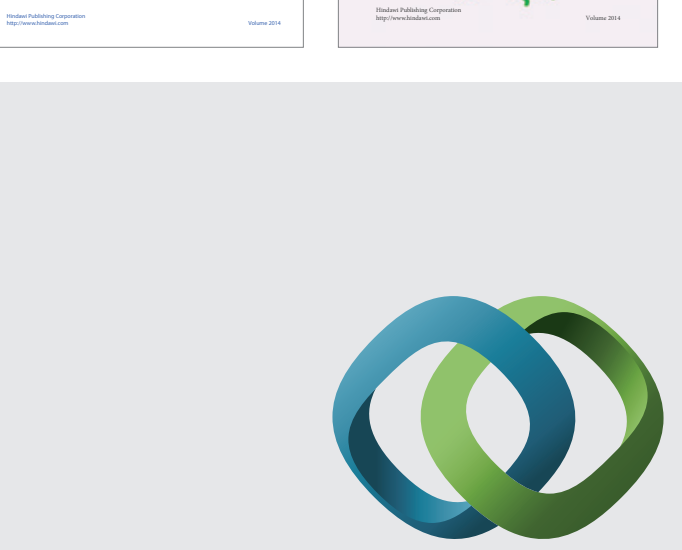

\section{Hindawi}

Submit your manuscripts at

http://www.hindawi.com
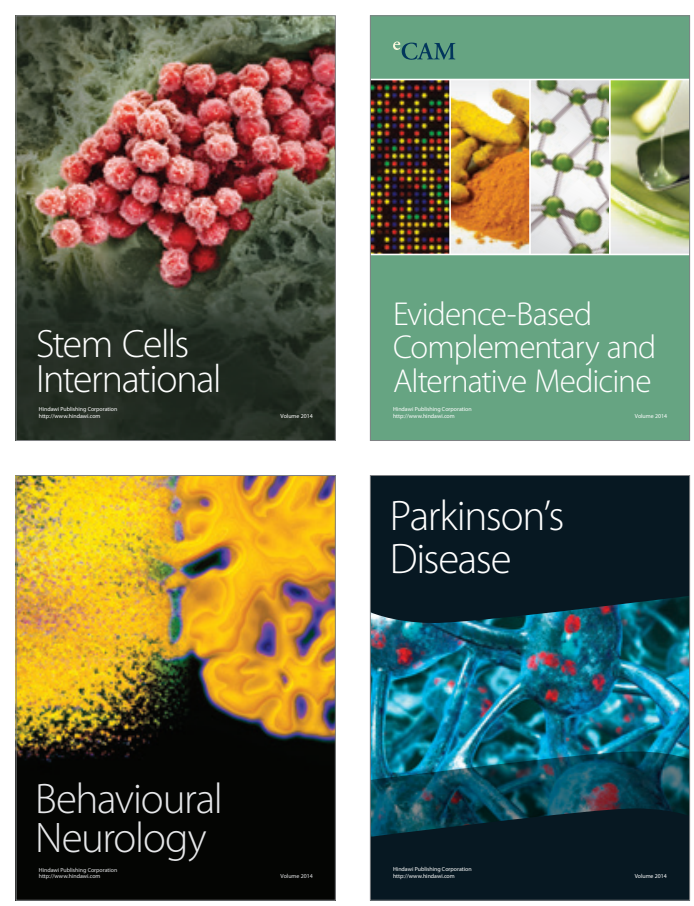

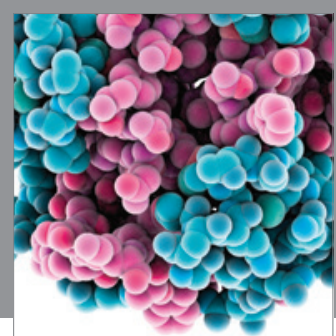

Journal of
Diabetes Research

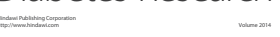

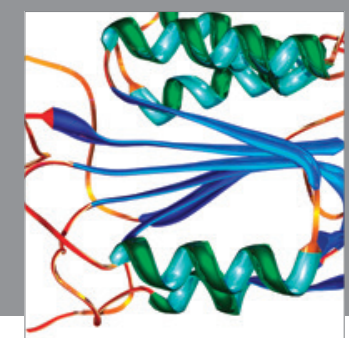

Disease Markers
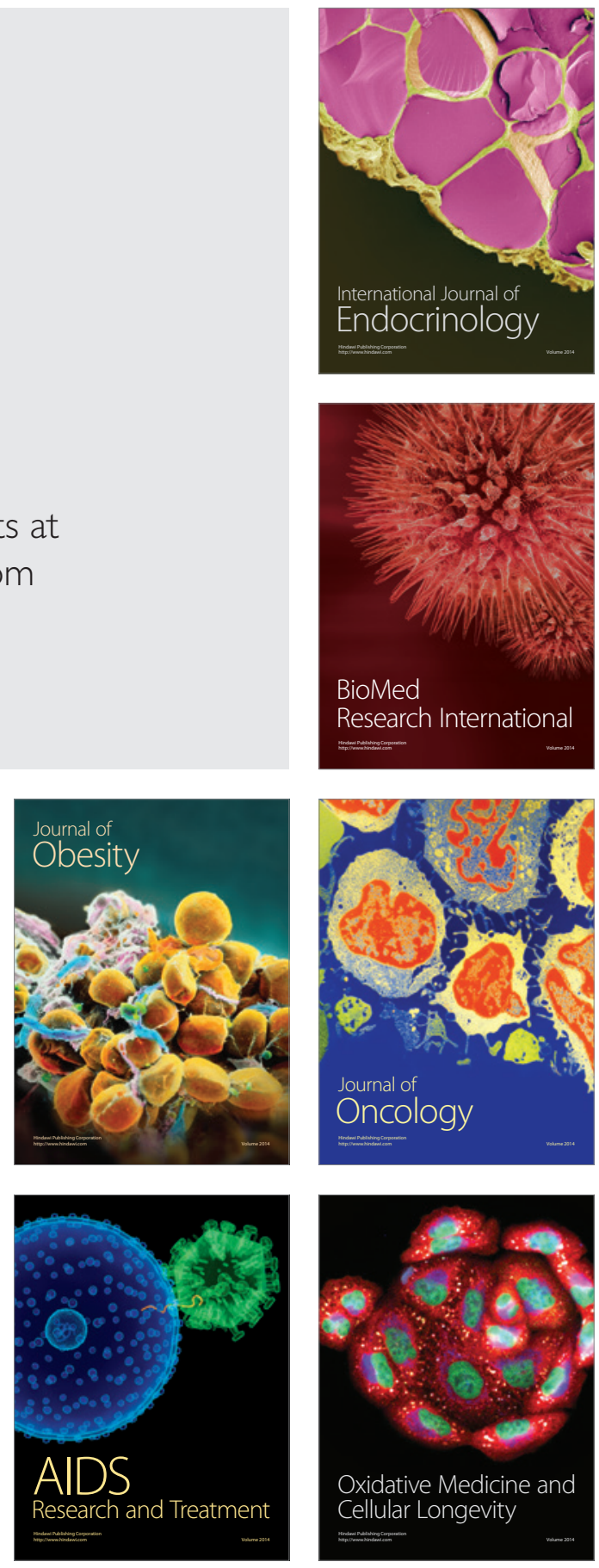